\title{
Hydrologic Vulnerability of Sagebrush Steppe Following Pinyon and Juniper Encroachment
}

\author{
Frederick B. Pierson, ${ }^{1}$ C. Jason Williams, ${ }^{2}$ Patrick R. Kormos, ${ }^{3}$ Stuart P. Hardegree, ${ }^{4}$ \\ Patrick E. Clark, ${ }^{5}$ and Benjamin M. Rau \\ Authors are ${ }^{1}$ Research Leader and Supervisory Research Hydrologist, ${ }^{2}$ Hydrologist, ${ }^{4}$ Research Plant Physiologist, and \\ ${ }^{5}$ Rangeland Scientist, Northwest Watershed Research Center, US Department of Agriculture (USDA) Agricultural Research Service, Boise, ID 83712, \\ USA, ${ }^{3}$ Graduate Student, Department of Geosciences, Boise State University, Boise, ID 83725, USA; and ${ }^{6}$ Research Assistant, Department of Natural \\ Resources and Environmental Science, University of Nevada, Reno, NV 89512, USA.
}

\begin{abstract}
Woodland encroachment on United States rangelands has altered the structure and function of shrub steppe ecosystems. The potential community structure is one where trees dominate, shrub and herbaceous species decline, and rock cover and bare soil area increase and become more interconnected. Research from the Desert Southwest United States has demonstrated areas under tree canopies effectively store water and soil resources, whereas areas between canopies (intercanopy) generate significantly more runoff and erosion. We investigated these relationships and the impacts of tree encroachment on runoff and erosion processes at two woodland sites in the Intermountain West, USA. Rainfall simulation and concentrated flow methodologies were employed to measure infiltration, runoff, and erosion from intercanopy and canopy areas at small-plot $\left(0.5 \mathrm{~m}^{2}\right)$ and large-plot $\left(13 \mathrm{~m}^{2}\right)$ scales. Soil water repellency and vegetative and ground cover factors that influence runoff and erosion were quantified. Runoff and erosion from rainsplash, sheet flow, and concentrated flow processes were significantly greater from intercanopy than canopy areas across small- and large-plot scales, and site-specific erodibility differences were observed. Runoff and erosion were primarily dictated by the type and quantity of ground cover. Litter offered protection from rainsplash effects, provided rainfall storage, mitigated soil water repellency impacts on infiltration, and contributed to aggregate stability. Runoff and erosion increased exponentially $\left(r^{2}=0.75\right.$ and 0.64$)$ where bare soil and rock cover exceeded $50 \%$. Sediment yield was strongly correlated $\left(r^{2}=0.87\right)$ with runoff and increased linearly where runoff exceeded $20 \mathrm{~mm} \cdot \mathrm{h}^{-1}$. Measured runoff and erosion rates suggest tree canopies represent areas of hydrologic stability, whereas intercanopy areas are vulnerable to runoff and erosion. Results indicate the overall hydrologic vulnerability of sagebrush steppe following woodland encroachment depends on the potential influence of tree dominance on bare intercanopy expanse and connectivity and the potential erodibility of intercanopy areas.
\end{abstract}

\section{Resumen}

La expansión del monte en pastizales de los Estados Unidos (EE.UU.) ha alterado la estructura y función de los ecosistemas de estepa arbustiva. La estructura potencial de la comunidad es aquella en la que los árboles son dominantes, las especies arbustivas y herbáceas declinan y la cobertura de rocas y suelo desnudo aumenta y se torna más interconectada. Investigaciones del Desierto del Sudoeste de los EE.UU. ha demostrado que las áreas debajo de los canopeos de los árboles efectivamente almacenan agua y recursos edáficos mientras que las áreas entre canopeos (el intercanopeo) generan significativamente más escorrentía superficial y erosión. Investigamos estas relaciones y los impactos de la invasión de árboles sobre los procesos de escurrimiento superficial y erosión en dos sitios de la región entre las Rocallosas y las Sierras Madre del Oeste de los EE.UU. Se emplearon metodologías de simulación de lluvias y flujo concentrado para medir infiltración, escurrimiento superficial, y erosión de áreas de intercanopeo y canopeo a escalas de parcelas pequeñas $\left(0.5 \mathrm{~m}^{2}\right)$ y grandes $\left(13 \mathrm{~m}^{2}\right)$. La escorrentía superficial y la erosión derivada del impacto de las gotas de lluvia y flujo laminar, y los procesos de flujo concentrado fueron significativamente mayores en áreas de intercanopeo que en áreas de canopeo tanto a escala de parcelas pequeñas como grandes, y se observaron diferencias sitio-específicas de propensión a la erosión. La escorrentía superficial y la erosión estuvieron determinadas principalmente por el tipo y la cantidad de cobertura basal. La broza ofreció protección de los efectos de las gotas de lluvia, proveyó almacenamiento de agua de lluvia, mitigó los impactos de la repelencia hídrica del suelo sobre la infiltración, y contribuyó a la estabilidad de los agregados. La escorrentía superficial y la erosión aumentaron de modo exponencial $\left(r^{2}=0.75\right.$ and 0.64 ) en lugares donde el suelo desnudo y la cobertura de roca fueron superiores al 50\%. La cantidad de sedimentos producida estuvo fuertemente correlacionada $\left(r^{2}=0.87\right)$ con la escorrentía superficial y aumentó de modo lineal en lugares donde el escurrimiento superficial superó los $20 \mathrm{~mm} \mathrm{~h}^{-1}$. Las tasas de escurrimiento superficial y erosión medidas sugieren que los canopeos de los árboles representan áreas de estabilidad hidrológica mientras que las áreas de intercanopeo son vulnerables

This is Contribution Number 15 of the Sagebrush Steppe Treatment Evaluation Project (SageSTEP), funded by the US Joint Fire Science Program.

Mention of a proprietary product does not constitute endorsement by USDA and does not imply its approval to the exclusion of the other products that may also be suitable.

Correspondence: Frederick B. Pierson, Northwest Watershed Research Center, USDA Agricultural Research Service, 800 Park Blvd, Plaza IV, Suite 105, Boise, ID 83712, USA. Email: fred.pierson@ars.usda.gov

Manuscript received 14 October 2009; manuscript accepted 27 June 2010. 
al escurrimiento superficial y la erosión. Los resultados indican que la vulnerabilidad hidrológica de la estepa de Artemisia luego de la expansión del monte depende de la influencia potencial de la dominancia de árboles sobre el área de intercanopeo y la conectividad y el potencial erosivo de dichas áreas.

Key Words: erosion, infiltration, runoff, SageSTEP, soil water repellency

\section{INTRODUCTION}

The 10-fold expansion in the density and distribution of pinyon (Pinus spp.) and juniper (Juniperus spp.) woodlands during the past $130 \mathrm{yr}$ has altered the ecological structure and function of shrub steppe ecosystems in the western United States (Burkhardt and Tisdale 1969; Tausch et al. 1981; Tausch and Tueller 1990; Tausch and West 1995; Bunting et al. 1999; Bates et al. 2000; Miller et al. 2000; Roberts and Jones 2000; Miller and Tausch 2001; Miller et al. 2005; Tausch and Hood 2007; Miller et al. 2008; Romme et al. 2009). Studies from wooded shrublands (shrublands with pinyon and/or juniper encroachment, see Romme et al. 2009) and pinyon-juniper woodlands suggest trees may have competitive advantages over intercanopy (areas between tree canopies) herbaceous plants and shrubs regarding resource acquisition and use (Doescher et al. 1987; Padien and Lajtha 1992; Breshears et al. 1997, 1998). Breshears et al. (1998) demonstrated that tree canopies in a New Mexico, USA, woodland modified soil temperature and evaporation regimes, and that soil microclimate alterations favored greater plantavailable soil water under trees relative to intercanopy areas during germination and growing seasons. Breshears et al. (1997) found the long lateral roots of pinyon and juniper trees are capable of extracting soil water from canopy and intercanopy areas. In contrast, intercanopy herbaceous species are limited to local soil water extraction by short, shallow root systems (Breshears et al. 1997, 1998). Therefore, trees potentially benefit from seasonally wetter soil conditions in canopy areas and their ability to compete for limited soil water resources in the intercanopy. Tree encroachment into shrub steppe then potentially elicits a vegetation pattern of tree dominance with minor shrub and herbaceous plant representation and expansive, spatially well-connected (Davenport et al. 1998), bare-soil intercanopy areas (Burkhardt and Tisdale 1969; Tausch et al. 1981; Tausch and West 1995; Bunting et al. 1999; Miller et al. 2000; Roberts and Jones 2000; Miller et al. 2005). These structural and functional vegetation alterations of historic shrub steppe have been linked to amplified runoff and erosion (Pierson et al. 2007a; Petersen and Stringham 2008).

Research from the southwestern United States indicates pinyon-juniper woodlands exist as either resource-conserving (Wilcox 1994; Reid et al. 1999; Wilcox et al. 2003) or rapidly degrading (Wilcox et al. 1996) rangelands depending on sitespecific erosion potential, surface soil protection, and climate (Davenport et al. 1998). Runoff and erosion on resourceconserving rangelands decrease with increasing spatial scale, whereas rapidly degrading rangelands exhibit increasing soil erosion with increasing land area (Wilcox et al. 2003). Wilcox et al. (2003) and Ludwig et al. (2005) proposed use of the trigger-transfer-reserve-pulse (TTRP) framework (see Ludwig et al. 1997) to conceptualize spatial transfers and retention of water and soil resources on southwestern US pinyon-juniper woodlands. The framework suggests storm events (triggers) spatially redistribute (transfer) water and soil resources from the bare intercanopy to well-vegetated intercanopy or canopy areas. Areas that gain water, soil, and nutrients store (reserve) and subsequently consume resources during plant reproduction and growth stages (pulse). Pulse events further sustain the resource-conserving nature of the system through canopy and ground cover recruitment and soil stabilization. Canopy areas mitigate losses of water, soil, and nutrients until the spatial arrangement of canopy and intercanopy is altered by disturbance (fire, grazing, drought, plant community transition, etc.; Schlesinger et al. 1990; Ludwig et al. 1997, 2005). Under this paradigm, a site is healthy (resource conserving) if only minor amounts of soil, water, and nutrients that enter the system are subsequently lost (Reid et al. 1999). Similar functional relationships have been observed for shrub canopy and interspace (areas between tree and shrub canopies) vegetative structure in Great Basin (USA) shrub steppe communities (Blackburn 1975; Pierson et al. 1994).

The coarsening of vegetation structure and soil heterogeneity with woodland encroachment and expansion across historic Great Basin shrub steppe (Burkhardt and Tisdale 1969; Tausch et al. 1981; Tausch and West 1995; Bunting et al. 1999; Miller et al. 2000; Roberts and Jones 2000; Romme et al. 2009) potentially alters the resource-conserving nature of these communities (Pierson et al. 2007a; Petersen and Stringham 2008). Scientists, land managers, and land owners require a decision framework for assessing site-specific hydrological impacts of woodland encroachment into shrub steppe ecosystems. Current site and rangeland health assessment strategies are confounded by the variation in site responses to woodland encroachment associated with the range of soil conditions, terrain, climate, plant communities, and land-use regimes in which pinyon and juniper exist (Miller and Wigand 1994; Miller et al. 2000, 2005; Romme et al. 2009). This study aims to improve understanding of the hydrologic vulnerability of Great Basin shrub steppe to amplified runoff and erosion following woodland encroachment and to provide insight into the key variables that dictate hydrologic responses of these ecosystems. A suite of rainfall simulation $\left(0.5-\mathrm{m}^{2}\right.$ and $13-\mathrm{m}^{2}$ scales $)$ and overland flow experiments were conducted on two woodland-encroached, historical shrub-steppe sites in the Great Basin. The primary objectives of the study were 1) to partition the relative contribution of intercanopy and canopy areas to hillslope runoff and erosion from rainsplash, sheet flow, and concentrated flow processes; 2) to investigate whether key soil and cover variables exist as indicators of hydrologic vulnerability; and 3) to evaluate relationships between runoff and erosional responses and several commonly assessed rangeland health parameters (aggregate stability, canopy and ground cover, canopy and basal gaps).

\section{METHODS}

This study is part of the larger Sagebrush Steppe Treatment Evaluation Project (SageSTEP) aimed at investigating the 
Table 1. Site descriptions for the Marking Corral and Onaqui study sites.

\begin{tabular}{|c|c|c|}
\hline Site characteristic & Marking Corral, Nevada & Onaqui, Utah \\
\hline Woodland community & Single-leaf pinyon ${ }^{1} /$ Utah juniper ${ }^{2}$ & Utah juniper ${ }^{2}$ \\
\hline Elevation $(\mathrm{m})$ & 2250 & 1720 \\
\hline Mean annual precipitation (mm) & $351^{3}$ & $345^{3}$ \\
\hline Mean annual air temperature $\left({ }^{\circ} \mathrm{C}\right)$ & $7.2^{4}$ & $7.5^{5}$ \\
\hline Slope $(\%)$ & $10-15$ & $10-15$ \\
\hline Parent rock & Andesite and rhyolite ${ }^{6}$ & Sandstone and limestone ${ }^{7}$ \\
\hline Soil association & Sequra-Upatad-Cropper ${ }^{6}$ & Borvant $^{7}$ \\
\hline Soil profile texture & Gravelly clay to clay loam ${ }^{6}$ & Gravelly loam ${ }^{7}$ \\
\hline Depth to bedrock (m) & $0.4-0.5^{6}$ & $1.0-1.5^{7}$ \\
\hline Depth to restrictive layer (m) & $0.4-0.5^{6}$ & $0.3-0.5^{7}$ \\
\hline Tree canopy cover (\%) & $15,^{1} 10^{2}$ & $26^{2}$ \\
\hline Trees per hectare & $329,{ }^{1} 150^{2}$ & $476^{2}$ \\
\hline Mean tree height $(\mathrm{m})$ & $2.3,^{1} 2.4^{2}$ & $2.4^{2}$ \\
\hline Dead shrubs per hectare & 2065 & 957 \\
\hline Understory vegetation & \multicolumn{2}{|c|}{$\begin{array}{l}\text { Artemisia tridentata Nutt. subsp. wyomingensis Beetle \& Young; Artemisia nova A. Nelson; Purshia spp. } \\
\text { Poa secunda J. Presl; Pseudoroegneria spicata (Pursh) A. Löve; and various forbs }\end{array}$} \\
\hline
\end{tabular}

${ }^{1}$ Pinus monophylla Torr. \& Frém.

${ }^{2}$ Juniperus osteosperma [Torr.] Little.

${ }^{3}$ Prism Group 2009.

${ }^{4}$ Western Regional Climate Center (WRCC), Station 264199-2, Kimberly, Nevada (WRCC 2009).

${ }^{5}$ WRCC, Station 424362-3, Johnson Pass, Utah (WRCC 2009).

${ }^{6}$ Natural Resources Conservation Service (NRCS) 2007.

${ }^{7}$ NRCS 2006.

ecological impacts of invasive species and woodland encroachment into sagebrush steppe ecosystems in the Great Basin and the effects of various sagebrush steppe restoration methods, including tree removal (McIver et al. 2010).

\section{Study Sites}

A single-leaf pinyon-Utah juniper site (Pinus monophylla Torr. and Frém-Juniperus osteosperma [Torr.] Little; Marking Corral, Nevada, USA) and a Utah juniper site (Onaqui, Utah, USA) were selected for hydrologic investigation within the SageSTEP study network (McIver et al. 2010). The Marking Corral site is located at lat $39^{\circ} 27^{\prime} 17^{\prime \prime}$, long $115^{\circ} 06^{\prime} 51^{\prime \prime}$ in the Egan Range, approximately $27 \mathrm{~km}$ northwest of Ely, Nevada. The Onaqui site is located at lat $40^{\circ} 12^{\prime} 42^{\prime \prime}$, long $112^{\circ} 28^{\prime} 24^{\prime \prime}$ in the Onaqui Mountains, $76 \mathrm{~km}$ southwest of Salt Lake City, Utah. Both study sites are managed by the Bureau of Land Management for grazing use but have been excluded from grazing since autumn 2005. Detailed site descriptions are provided in Table 1.

\section{Experimental Design and Plot Installation}

Rainfall simulations were conducted at the small-plot $(0.7 \times 0.7 \mathrm{~m})$ and large-plot $(2 \times 6.5 \mathrm{~m})$ scales. Small-plot simulations were used to quantify runoff and erosion from rainsplash and sheet flow (Pierson et al. 2001, 2002, 2008a, 2008b, 2009) and large-plot simulations were used to quantify runoff and erosion from rainsplash, sheet flow, and concentrated flow processes (Pierson et al. 2007a, 2009). Each small plot was placed underneath either a shrub canopy (shrub coppice), juniper canopy (juniper coppice), pinyon canopy (pinyon coppice), or in the interspace area to partition respective microsite contributions to runoff and erosion from the small plot to the patch scale $\left(10-20 \mathrm{~m}^{2}\right)$. Large plots were installed on either shrub-interspace zones (varying amounts of shrub cover and interspace) or tree zones (juniper or pinyon coppice with minor interspace component) to evaluate runoff and erosion contributions from the tree coppice and shrubinterspace patch scale to the hillslope scale. The total number of small and large plots by microsite is shown in Tables 2 and 3 .

Small-plot frames were pounded into place immediately before simulation with the use of a steel bar and were left in place for sampling in subsequent years. Large plots were installed in pairs oriented with the long axis perpendicular to the predominant hillslope contour (Fig. 1). Sheet-metal plot walls and collection troughs (see Fig. 1) were inserted approximately $5 \mathrm{~cm}$ into the soil profile. Collection troughs were installed in a " $\mathrm{V}$ " pattern from plot walls to the runoff collection point. Plot wall and collection trough intersections were sealed with the use of a mixture of native soil and cement sealer to prevent inflow and outflow of water, to stop undercutting, and to minimize error in soil-erosion measurement due to artificial disturbance. The minimal disturbance along plot walls was backfilled and compacted. Trees were removed (cut by chainsaw) from rainfall simulation plots to eliminate canopy interference with rainfall distribution. Shrubs were trimmed along plot boundaries to prevent stemflow from exiting or entering the plot.

\section{Vegetation and Soils}

Hillslope-scale tree cover and tree and dead-shrub density were determined from $30 \times 33 \mathrm{~m}$ randomly located vegetation plots at each site (six at Marking Corral, nine at Onaqui). The number of trees greater than $0.5-\mathrm{m}$ height was recorded for each plot. Tree height and the maximum and minimum crown diameters were measured for each tallied tree (Mueller- 
Table 2. Average topography, soil, and cover variables observed on small $\left(0.5 \mathrm{~m}^{2}\right)$ rainfall simulation plots. Means within a row followed by a different lowercase letter are significantly different $(P<0.05)$.

\begin{tabular}{|c|c|c|c|c|c|c|c|}
\hline \multirow[b]{2}{*}{ Site characteristic } & \multicolumn{4}{|c|}{ Marking Corral } & \multicolumn{3}{|c|}{ Onaqui } \\
\hline & Interspace & $\begin{array}{l}\text { Juniper } \\
\text { coppice }\end{array}$ & $\begin{array}{l}\text { Pinyon } \\
\text { coppice }\end{array}$ & $\begin{array}{l}\text { Shrub } \\
\text { coppice }\end{array}$ & Interspace & $\begin{array}{l}\text { Juniper } \\
\text { coppice }\end{array}$ & $\begin{array}{c}\text { Shrub } \\
\text { coppice }\end{array}$ \\
\hline Slope $(\%)$ & $10.1 \mathrm{a}$ & $14.1 \mathrm{bc}$ & $16.7 \mathrm{~cd}$ & $11.5 \mathrm{ab}$ & $15.6 \mathrm{~cd}$ & 20.3 e & 18.2 de \\
\hline Gravimetric soil water content $(0-5 \mathrm{~cm}$ depth, \%) & $1.7 \mathrm{a}$ & $4.5 \mathrm{~b}$ & $5.9 \mathrm{~b}$ & $1.9 \mathrm{a}$ & $5.9 \mathrm{~b}$ & $5.3 \mathrm{~b}$ & $4.1 \mathrm{~b}$ \\
\hline Aggregate stability class $(0-6)^{1}$ & $2 \mathrm{a}$ & $5 \mathrm{c}$ & $5 \mathrm{c}$ & $3 a b$ & $3 a b$ & $5 \mathrm{c}$ & $4 \mathrm{~b}$ \\
\hline Surface roughness $(\mathrm{mm})$ & $8 \mathrm{a}$ & $11 \mathrm{~b}$ & $14 \mathrm{bc}$ & $15 \mathrm{c}$ & $12 \mathrm{~b}$ & $12 \mathrm{~b}$ & $16 c$ \\
\hline Total canopy cover $(\%)^{2}$ & $21.1 \mathrm{~b}$ & $7.5 \mathrm{a}$ & $12.7 \mathrm{ab}$ & $85.8 \mathrm{~d}$ & $11.7 \mathrm{a}$ & $8.1 \mathrm{a}$ & $62.7 \mathrm{c}$ \\
\hline Total herbaceous canopy cover (\%) & $18.1 d$ & $4.0 \mathrm{ab}$ & $0.3 \mathrm{a}$ & $15.7 \mathrm{~cd}$ & $10.3 b c$ & $5.8 a b$ & $9.7 \mathrm{bc}$ \\
\hline Shrub canopy cover $(\%)$ & $0.5 \mathrm{a}$ & $0.0 \mathrm{a}$ & $1.5 \mathrm{a}$ & $60.8 \mathrm{c}$ & $0.1 \mathrm{a}$ & $0.0 \mathrm{a}$ & $48.0 \mathrm{~b}$ \\
\hline Grass canopy cover (\%) & $17.1 \mathrm{c}$ & $3.2 \mathrm{a}$ & $0.3 \mathrm{a}$ & $13.5 \mathrm{bc}$ & $5.7 \mathrm{a}$ & $5.0 \mathrm{a}$ & $8.2 a b$ \\
\hline Litter cover (\%) & $7.6 \mathrm{a}$ & $98.4 \mathrm{~d}$ & $93.9 \mathrm{~d}$ & $64.8 \mathrm{c}$ & $2.7 \mathrm{a}$ & $95.3 \mathrm{~d}$ & $36.2 \mathrm{~b}$ \\
\hline Rock cover (\%) & $46.1 \mathrm{C}$ & $0.4 \mathrm{a}$ & $0.1 \mathrm{a}$ & $8.8 \mathrm{a}$ & $46.1 \mathrm{c}$ & $0.6 \mathrm{a}$ & $21.3 b$ \\
\hline Total ground cover $(\%)$ & $56.0 \mathrm{a}$ & $99.7 d$ & $99.9 \mathrm{~d}$ & $78.2 \mathrm{c}$ & $57.4 \mathrm{a}$ & $98.7 \mathrm{~d}$ & $69.1 \mathrm{~b}$ \\
\hline Bare soil (\%) & $44.0 \mathrm{~d}$ & $0.3 \mathrm{a}$ & $0.1 \mathrm{a}$ & $21.8 \mathrm{c}$ & $42.6 \mathrm{~d}$ & $1.3 \mathrm{a}$ & $30.9 \mathrm{c}$ \\
\hline Litter depth (cm) & $<1 \mathrm{a}$ & $7 \mathrm{c}$ & $9 \mathrm{c}$ & $<1 \mathrm{a}$ & $<1 \mathrm{a}$ & $5 \mathrm{~b}$ & $<1 \mathrm{a}$ \\
\hline No. of plots & 23 & 12 & 12 & 13 & 33 & 19 & 18 \\
\hline
\end{tabular}

${ }^{1}$ Stability classes: 0, unstable; $1-3$, less than 10\% stable aggregates, 50\% structural integrity lost within $5 \mathrm{~s}$ (1), 5-30 s (2), and 30-300 s (3), respectively; (4) 10-25\% stable aggregates; (5) $25-75 \%$ stable aggregates; (6) $75-100 \%$ stable aggregates (Herrick et al. 2001, 2005).

${ }^{2}$ Excludes tree canopy removed for rainfall simulation.

Dombois and Ellenberg 1974). The crown radius for each tree was calculated as one-half the average of the minimum and maximum crown diameters. Individual tree crown cover was assumed equivalent to the area of a circle, calculated with the respective crown radius (Mueller-Dombois and Ellenberg 1974). The total tree cover for each plot was determined as the sum of measured individual tree-cover values on the respective plot. The number of dead shrubs greater than $5-\mathrm{cm}$ height were counted along three evenly spaced ( $6 \mathrm{~m}$ apart) belt transects $(2 \times 30 \mathrm{~m})$ within each $30 \times 33 \mathrm{~m}$ plot. Site average tree and dead-shrub variables were estimated as the average of measurements from the $30 \times 33 \mathrm{~m}$ vegetation plots.
Canopy cover, ground cover, and surface roughness on small plots were measured with a point frame (Mueller-Dombois and Ellenberg 1974). Seven evenly spaced transects of 15 points (parallel to hillslope contour, $5-\mathrm{cm}$ spacing) were sampled on each plot. Percent cover was determined from the frequency of hits divided by the total number of points (105) sampled within the plot. The relative ground-surface height at each point was calculated as the distance between the point-frame level line and the ground surface at the respective point. Surface roughness was estimated as the arithmetic average of the standard deviations of the ground surface heights for each of the seven transects sampled within each plot (Pierson et al. 2007b).

Table 3. Average topography, soil water content, and cover gaps observed on large $\left(13 \mathrm{~m}^{2}\right)$ rainfall simulation plots. Means within a row followed by a different lowercase letter are significantly different $(P<0.05)$.

\begin{tabular}{|c|c|c|c|c|}
\hline \multirow[b]{2}{*}{ Site characteristic } & \multicolumn{2}{|c|}{ Marking Corral } & \multicolumn{2}{|c|}{ Onaqui } \\
\hline & Shrub-interspace zone & Tree zone & Shrub-interspace zone & Tree zone \\
\hline Slope $(\%)$ & $9.3 \mathrm{a}$ & $9.3 \mathrm{a}$ & $14.0 \mathrm{~b}$ & $14.6 \mathrm{~b}$ \\
\hline Gravimetric soil water content $(0-5 \mathrm{~cm}$ depth, \%) & $5.6 \mathrm{a}$ & $11.1 \mathrm{~b}$ & $6.6 \mathrm{a}$ & $8.9 \mathrm{ab}$ \\
\hline Surface roughness $(\mathrm{mm})$ & $17 \mathrm{a}$ & $20 a b$ & $26 \mathrm{bc}$ & $31 \mathrm{c}$ \\
\hline Canopy gaps $25-50 \mathrm{~cm}(\%)^{1}$ & $10 \mathrm{~b}$ & $3 a$ & $9 \mathrm{~b}$ & $10 \mathrm{~b}$ \\
\hline Canopy gaps $51-100 \mathrm{~cm}(\%)^{1}$ & $19 \mathrm{bc}$ & $10 \mathrm{a}$ & $20 c$ & $15 a b$ \\
\hline Canopy gaps $101-200 \mathrm{~cm}(\%)^{1}$ & $30 \mathrm{c}$ & $15 \mathrm{a}$ & $25 \mathrm{bc}$ & $19 a b$ \\
\hline Canopy gaps $201-600 \mathrm{~cm}(\%)^{1}$ & $6 \mathrm{a}$ & $55 \mathrm{c}$ & $22 \mathrm{~b}$ & $25 \mathrm{~b}$ \\
\hline Basal gaps $25-50 \mathrm{~cm}(\%)$ & $6 \mathrm{~b}$ & $1 \mathrm{a}$ & $7 \mathrm{~b}$ & $10 \mathrm{c}$ \\
\hline Basal gaps $51-100$ cm (\%) & $15 b$ & $4 \mathrm{a}$ & $15 b$ & $12 \mathrm{~b}$ \\
\hline Basal gaps $101-200$ cm (\%) & $34 \mathrm{c}$ & $5 \mathrm{a}$ & $26 \mathrm{bc}$ & $20 \mathrm{~b}$ \\
\hline Basal gaps $201-600 \mathrm{~cm} \mathrm{( \% )}$ & $37 \mathrm{a}$ & $80 \mathrm{~b}$ & $42 \mathrm{a}$ & $42 \mathrm{a}$ \\
\hline Average canopy gap $(\mathrm{cm})^{1}$ & $75 \mathrm{a}$ & $202 \mathrm{~b}$ & $92 \mathrm{a}$ & $85 \mathrm{a}$ \\
\hline Average basal gap (cm) & $125 \mathrm{a}$ & $305 \mathrm{~b}$ & $118 \mathrm{a}$ & $115 \mathrm{a}$ \\
\hline No. of plots & 12 & 12 & 18 & 18 \\
\hline
\end{tabular}

${ }^{1}$ Canopy gaps measured after tree removal for rainfall simulation. 
A

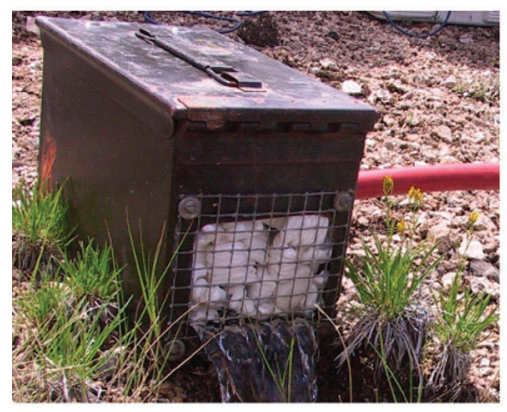

B

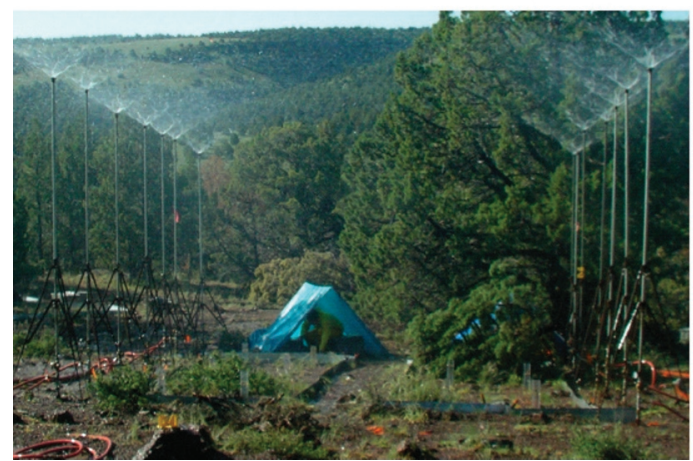

C $7.6 \mathrm{~cm}$ diameter hose

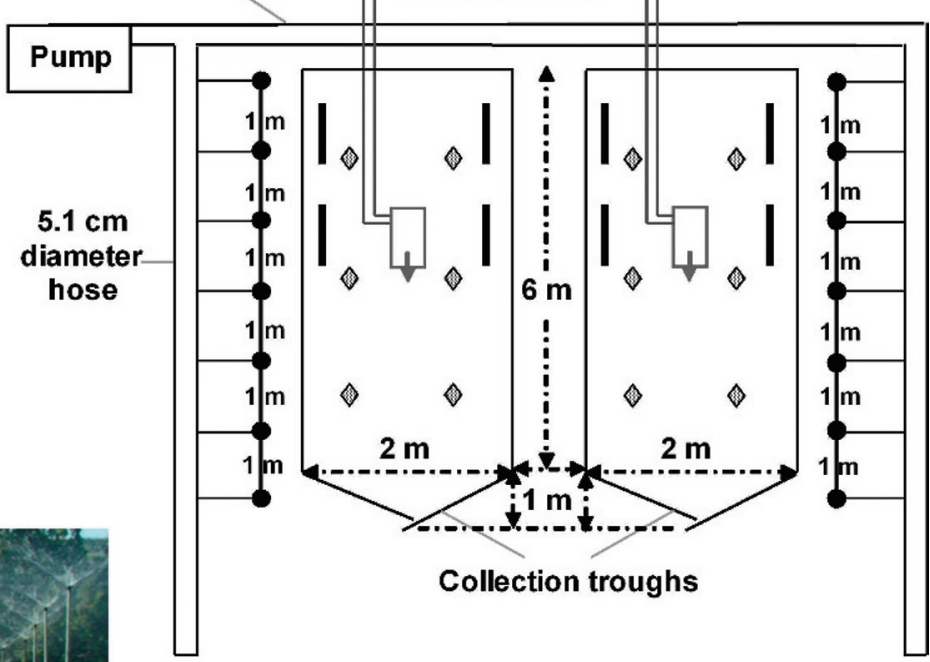

- $3.05 \mathrm{~m}$ tall sprinkler stand pipe

- Approximate rain gage location

I Approximate wetting trench location

Approximate location of concentrated flow release point, arrow indicates flow direction and release opening

Figure 1. Illustration of paired large rainfall plot layout and design showing A, concentrated flow release point; $\mathbf{B}$, large rainfall plot instrumentation; and $\mathbf{C}$, drawing of paired large rainfall plot layout.

Canopy and ground cover on large rainfall simulation plots were estimated with the use of line-point intercept procedures (Herrick et al. 2005). Canopy and ground cover were recorded for 59 points with $10-\mathrm{cm}$ spacing, along each of five evenly spaced $(40 \mathrm{~cm}$ apart, perpendicular to hillslope contour) transects $6 \mathrm{~m}$ in length $(295$ total points; Herrick et al. 2005). The relative ground-surface height along line-intercept transects was calculated as on small plots, using a survey transit to establish the level line. Surface roughness on large plots was estimated as the arithmetic average of the standard deviations of the ground surface heights across the five line-point transects sampled within each plot (Moffet et al. 2007).

Canopy and basal cover gaps on large rainfall plots were estimated using the gap-intercept method along the canopy and ground cover line-point transects (Herrick et al. 2005). The distances between plant canopies (canopy gaps) and bases (basal gaps) are considered indicators of potential runoff and erosion (Herrick et al. 2005). Percentages of canopy and basal gaps representing $25-50 \mathrm{~cm}, 51-100 \mathrm{~cm}, 101-200 \mathrm{~cm}$, and $201-600 \mathrm{~cm}$ of each transect were determined and averaged across the five transects to determine plot means by gap size class (Herrick et al. 2005). In general, runoff and erosion are expected to increase where gap sizes consistently exceed 50 $100 \mathrm{~cm}$ (Herrick et al. 2005).

Litter depths were measured adjacent to each small plot at four evenly spaced points along each of the two plot borders perpendicular to the hillslope contour. Litter mass samples $\left(0.03 \mathrm{~cm}^{2}\right)$ were obtained by pounding in a metal cylinder every $30 \mathrm{~cm}$ along a transect from the base of a tree to the edge of the coppice at 10 representative locations on juniper and pinyon microsites at Marking Corral and on juniper microsites at Onaqui. Each sample was oven dried at $60^{\circ} \mathrm{C}$ and weighed to determine sample mass.

Surface soils were characterized by sampling random surface locations and all rainfall simulation plots at each site. Surfacesoil grab samples (0-2-cm depth) were obtained from each study site and were analyzed for soil texture with the use of a Saturn DigiSizer Particle Size Analyzer (Micromeritics Instrument Corporation). Plot soil samples were obtained $(0-5-\mathrm{cm}$ depth) adjacent to each small, large, and concentrated flow plot immediately before the respective simulation, and were analyzed gravimetrically for soil water content. Bulk density $(0-4-\mathrm{cm}$ depth) was measured at multiple locations at each study site with the use of the compliant cavity method (Grossman and Pringle 1987).

Surface-soil aggregate stability at each small plot was assessed as the average of the percent remaining of six aggregates following immersion in water (see Herrick et al. 2001, 2005). Each sample was immersed for $5 \mathrm{~min}$. Aggregates persisting after 5 min were subjected to a sequence of five 1-s immersions (Herrick et al. 2001, 2005). Samples were assigned a stability class as follows: 0 , soil too unstable to sample; 1 , $50 \%$ structural integrity lost within $5 \mathrm{~s}$ of immersion; $2,50 \%$ structural integrity lost within 5-30 s of immersion; 3, 50\% structural integrity lost within 30-300 s of immersion or less than $10 \%$ soil remaining after five immersions; $4,10-25 \%$ soil remains after five immersions; $5,25-75 \%$ soil remains after five immersions; $6,75-100 \%$ soil remains after five immersions. Aggregate stability values of 5 or better indicate good resistance to erosion (Herrick et al. 2005). 
Soil water repellency was measured before rainfall simulation immediately adjacent to each small plot using the water drop penetration time (WDPT) procedure (see DeBano 1981). Eight water drops (approximately $3-\mathrm{cm}$ spacing) were applied to the mineral soil surface and the time required for infiltration was recorded up to $300 \mathrm{~s}$. Following this procedure $1 \mathrm{~cm}$ of soil was excavated immediately underneath the previously sampled area and the WDPT procedure was repeated for eight additional drops. This process was repeated until a depth of $5 \mathrm{~cm}$ was reached. Mean water repellency at each depth for each plot was recorded as the mean of the eight WDPT (s) samples. Soils were considered water repellent if WDPT exceeded $5 \mathrm{~s}$, slightly water repellent if WDPT ranged from $5 \mathrm{~s}$ to $60 \mathrm{~s}$, and strongly water repellent if WDPT ranged from $60 \mathrm{~s}$ to $600 \mathrm{~s}$ (Bisdom et al. 1993).

\section{Rainfall Simulation}

Rainfall was applied to small and large plots at rates of $64 \mathrm{~mm} \cdot \mathrm{h}^{-1}$ (dry run) and $102 \mathrm{~mm} \cdot \mathrm{h}^{-1}$ (wet run) for $45 \mathrm{~min}$. The dry run was conducted on uniform dry antecedent soil moisture conditions, and the wet run began within $30 \mathrm{~min}$ following the dry run. The dry-run intensity over 5-min, 10-min, and 15 -min durations is equivalent to respective storm return intervals of $7 \mathrm{yr}, 15 \mathrm{yr}$, and $25 \mathrm{yr}$ (Bonnin et al. 2006). The wetrun intensity over 5 - $\mathrm{min}, 10-\mathrm{min}$, and 15 -min durations is equivalent to respective storm return intervals of $25 \mathrm{yr}, 60 \mathrm{yr}$, and $120 \mathrm{yr}$ (Bonnin et al. 2006). Rainfall was applied to small plots with the use of a portable oscillating-arm rainfall simulator fitted with 80-100 Veejet nozzles (Meyer and Harmon 1979; Pierson et al. 2001, 2002, 2008a, 2009). Paired large rainfall simulations (Figs. 1B and 1C) were conducted with the use of a Colorado State University (CSU) -type rainfall simulator (Holland 1969; Pierson et al. 2007a, 2009) with stationary sprinklers elevated $3.05 \mathrm{~m}$ above the soil surface. Raindrop size $(2 \mathrm{~mm})$ and kinetic energy $\left(200 \mathrm{~kJ} \cdot \mathrm{ha}^{-1} \cdot \mathrm{mm}^{-1}\right)$ of simulated rainfall were within approximately $1 \mathrm{~mm}$ and $70 \mathrm{~kJ} \cdot \mathrm{ha}^{-1} \cdot \mathrm{mm}^{-1}$, respectively, of values reported for natural convective rainfall (Holland 1969; Carter et al. 1974; Meyer and Harmon 1979). The total amount of rainfall applied to each small plot was obtained by integrating the pan catch of a 5-min calibration run prior to each rainfall simulation. Calibration pans were designed to fit directly on plot frames without disturbing the plot surface. Total rainfall was estimated on plots where shrub cover prevented placement of calibration pans. Estimated rainfall was calculated as the average of all calibrations for the respective simulation date. Total rainfall applied to large plots was determined from the average of six plastic depth gages placed on a uniform grid within each plot (Fig. 1C).

Timed samples of small- and large-plot runoff were collected at 1-3-min intervals throughout each 45-min simulation and analyzed for runoff volume and sediment concentration. Runoff from direct rainfall on the large-plot collection troughs (trough catch; see Fig. 1) was estimated by sampling collection trough runoff before plot-generated runoff occurred. Runoff volume and sediment concentration were measured for each runoff sample by weighing the sample before and after drying at $105^{\circ} \mathrm{C}$. Sample weights were adjusted to account for trough catch.

Multiple response variables were calculated for each small and large plot. The mean runoff rate $\left(\mathrm{mm} \cdot \mathrm{h}^{-1}\right)$ was calculated for each sample interval as the interval runoff divided by the interval time. Cumulative runoff $(\mathrm{mm})$ was calculated as the integration of runoff rates over the total time of runoff. The percentage of rainfall converted to runoff was calculated as a runoff-to-rainfall ratio $\left(\mathrm{mm} \cdot \mathrm{mm}^{-1}\right)$, cumulative runoff divided by total rainfall applied, multiplied by $100 \%$. Infiltration and sediment variables were only calculated for plots that generated runoff. The average infiltration rate $\left(\mathrm{mm} \cdot \mathrm{h}^{-1}\right)$ for each sample interval was calculated as the difference between applied rainfall and measured runoff divided by the time of the sample interval. A final infiltration rate $\left(\mathrm{mm} \cdot \mathrm{h}^{-1}\right)$ was estimated as the average infiltration rate of the 43-45-min time interval. The minimum infiltration rate $\left(\mathrm{mm} \cdot \mathrm{h}^{-1}\right)$ was chosen as the lowest average infiltration rate of all intervals. Cumulative sediment yield $\left(\mathrm{g} \cdot \mathrm{m}^{-2}\right)$ was calculated as the integrated sum of sediment collected during runoff and was extrapolated to a unit area based on plot size. A sediment-torunoff ratio $\left(\mathrm{g} \cdot \mathrm{m}^{-2} \cdot \mathrm{mm}^{-1}\right)$ was calculated by dividing cumulative sediment yield by cumulative runoff.

Wetting patterns were investigated on large plots immediately following wet runs by excavating four $50-\mathrm{cm}$ trenches to a depth of $20 \mathrm{~cm}$ (Fig. 1; Pierson et al. 2008b, 2009). The percent wetted area of the exposed soil profile was measured with the use of a $4-\mathrm{cm}^{2}$ grid, where each grid area was determined to be dry or wet based on the dominant condition in the grid area. The area wet to $6-\mathrm{cm}, 10-\mathrm{cm}$, and $20-\mathrm{cm}$ depths was recorded as the percentage of wetted area within the excavated trench from $0-6-\mathrm{cm}, 0-10-\mathrm{cm}$, and $0-20-\mathrm{cm}$ depths. Mean values for the $6-\mathrm{cm}, 10-\mathrm{cm}$, and $20-\mathrm{cm}$ depths were recorded as the average of the four excavated trenches.

\section{Concentrated Flow Simulation}

Concentrated flow simulations were conducted to assess runoff and erosion from rill processes. Computer-controlled flow regulators (Moffet et al. 2007; Pierson et al. 2007a, 2008a, 2009) were used to apply concentrated flow release rates of 15 , 30 , and $45 \mathrm{~L} \cdot \min ^{-1}$ to each large plot at each study site starting approximately $2 \mathrm{~h}$ after rainfall simulation. Flow was routed through a metal box filled with styrofoam pellets, to dissipate kinetic energy, and was released through a $10-\mathrm{cm}-$ wide mesh-screened opening at the base of the box (Fig. 1A). Each flow release on each plot was applied for $12 \mathrm{~min}$ from the same release-point location, $4 \mathrm{~m}$ upslope of the collectiontrough apex (Fig. 1C). Release-rate progression was consecutive from $15 \mathrm{~L} \cdot \min ^{-1}$ to $45 \mathrm{~L} \cdot \mathrm{min}^{-1}$. Flow samples were collected at approximately 2-min intervals for each 12-min simulation at each release rate. Flow samples were weighed, oven dried at $105^{\circ} \mathrm{C}$, then reweighed to determine runoff rate and sediment concentration. Runoff and sediment yield variables for each release rate were calculated for an 8 -min time period beginning at the time of runoff initiation. The 8min runoff and sediment variables were calculated as described for the 45-min rainfall simulations. Flow velocity was measured by releasing a concentrated salt solution into the flow and using electrical conductivity probes to track the mean transit time of the salt over a known flow path length (Moffet et al. 2007, Pierson et al. 2007a, 2008a, 2009). The width, depth, and total rill area width of flowing water were measured along flow cross sections $3 \mathrm{~m}$ down slope from the release 


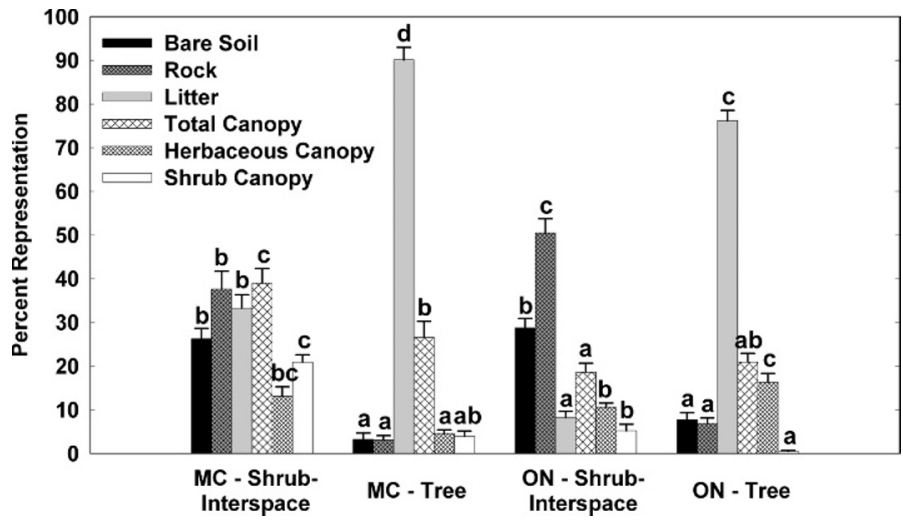

Figure 2. Bare soil representation and rock, litter, total canopy (after tree removal), herbaceous canopy (grass and forb), and shrub canopy cover measured on large rainfall plots $\left(13 \mathrm{~m}^{2}\right)$ at the Marking Corral (MC) and Onaqui (ON) study sites, stratified as shrub-interspace and tree zones. Error bars depict standard error. Means within a cover type (i.e., total canopy) followed by different lowercase letters are significantly different $(P<0.05)$.

point. Total rill area width represents the total width between the outermost edges of the outermost flow paths at the respective cross section (Pierson et al. 2008a, 2009).

\section{Data Analysis}

Analysis of variance was used to test for significant differences among microsites and sites. A mixed-effect model was applied, treating plot location as a random effect and site and microsite as fixed effects (Littel et al. 2006). Means were separated with the use of the Fisher's protected least significant difference test $(\alpha=0.05$; SAS Institute 1999). Log and arcsine square-root transformations were used where necessary to normalize data. Backtransformed data are reported. All reported correlations were tested for significance with $\alpha=0.05$.

\section{RESULTS}

\section{Vegetation, Water Repellency, and Soils}

The observed preponderance of shrub skeletons in shrubinterspace zones at Marking Corral and Onaqui indicate coarsening of the vegetative structure with increasing tree dominance, and the lack of observed large tree stumps and woody debris imply the emergence of tree co-dominance was through tree encroachment into historic sagebrush steppe (Miller et al. 2005; Tausch and Hood 2007; Miller et al. 2008). Shrub-interspace zones represented approximately $75 \%$ of both study areas and were extensively covered with dead shrubs (Table 1 ). Tree cover was approximately $25 \%$ across sites (Table 1). Live tree density approached 480 trees per hectare, and mean tree height was $2.4 \mathrm{~m}$ (Table 1). Woodland encroachment has been categorized into three phases: 1) Phase I, trees actively expanding, but shrubs and herbaceous species are dominant vegetation; 2) Phase II, tree cover expanding (10-30\% canopy cover) and shrub layer is nearly intact or is thinning; and 3) Phase III, tree expansion is nearly stabilized (more than $30 \%$ canopy cover) and more than $75 \%$ of shrub layer is dead (Miller et al. 2008). The collective tree canopy cover, mean tree heights, extensive shrub skeletons, and observed tree recruitment indicate the Marking Corral and Onaqui sites are overall in Phase II, but nearing early Phase III woodland encroachment and tree dominance (Tausch and Hood 2007; Miller et al. 2008).

The ground surface across plot scales was bare soil and rock dominated on interspaces and in shrub-interspace zones, moderately covered by litter under shrubs, and extensively covered by litter under trees (Table 2, Fig. 2). Bare soil and rock cover approximated $60-80 \%$ across shrub-interspace zones at both sites (Fig. 2). Litter cover under shrub canopies was $36-65 \%$, but was less than $1 \mathrm{~cm}$ deep (Table 2). Interspace small plots had less than $10 \%$ litter cover (Table 2). Small and large tree plots were approximately $80-100 \%$ covered by a $5-$ 9-cm-thick litter layer (Table 2, Fig. 2). Litter mass measured underneath trees was $19.7 \mathrm{~kg} \cdot \mathrm{m}^{-2}$ and $15.1 \mathrm{~kg} \cdot \mathrm{m}^{-2}$, respectively, for juniper and pinyon at Marking Corral and was $14.3 \mathrm{~kg} \cdot \mathrm{m}^{-2}$ for juniper at Onaqui. The primary differences in ground cover between the two study sites were the amounts of litter and rock cover on shrub microsites (Table 2) and in shrub-interspace zones (Fig. 2). Onaqui shrub-interspace zones had $75 \%$ less litter cover and 34\% more rock compared to Marking Corral.

The site-level differences in spatial litter recruitment result in part from the differences in shrub and grass canopy cover between the sites (Table 2). Small-plot shrub canopy cover at Marking Corral was 20\% greater than measured at Onaqui, and grass canopy cover on interspace microsites at Marking Corral was threefold more than measured at Onaqui. These site differences at the small-plot scale manifest into greater total canopy cover and litter cover in shrub-interspace zones at Marking Corral than Onaqui (Fig. 2). Total canopy cover on large tree plots at both sites was low because of tree removal during plot installation and minor representation by shrub species (Fig. 2).

The extensiveness of canopy and basal gaps in excess of $100 \mathrm{~cm}$ indicate high erosion potential for all large plots. Canopy and basal gaps were generally large $(\geq 75 \mathrm{~cm}$, Table 3). Approximately $50 \%$ of canopy gaps and $70 \%$ of basal gaps exceeded $100 \mathrm{~cm}$ in length at both sites (Table 3). Canopy and basal gaps in excess of $200 \mathrm{~cm}$ accounted for most of the measured gaps on Marking Corral tree plots. Average canopy and basal gaps were more than twofold greater in tree zones than interspace zones at Marking Corral (Table 3). No significant differences were found between tree and shrubinterspace zone average canopy and basal gaps at Onaqui. Microsite differences in gap sizes at Marking Corral are attributed to the microsite differences in total canopy cover (Fig. 2).

Litter material under tree and shrub canopies coincided with greater aggregate stability and contributed to surface roughness at the small-plot scale (Table 2). Aggregate stability tests indicate soil aggregates were $25-75 \%$ stable under tree canopies, less than 10-25\% stable under shrub canopies, and less than $10 \%$ stable on interspace plots (Table 2). Small-plot surface roughness was highest under shrub and tree canopies and on Onaqui interspaces (Table 2). Surface roughness at the large-plot scale was slightly higher at Onaqui than Marking Corral by microsite, but differences between microsites at a site were not significant (Table 3). Similarities in large-plot micro- 


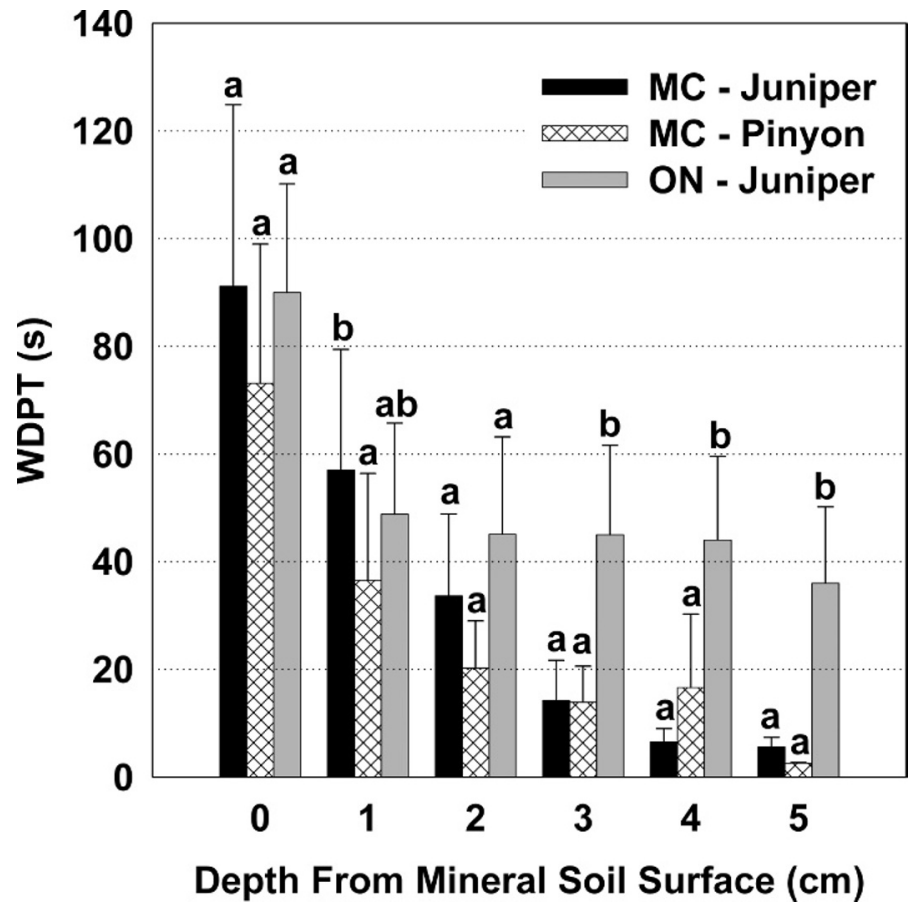

Figure 3. Water drop penetration times (WDPT, 300-s maximum) measured under tree canopies on small rainfall plots $\left(0.5 \mathrm{~m}^{2}\right)$ at the Marking Corral (MC) and Onaqui (ON) study sites. Soils were considered water repellent when WDPT exceeded $5 \mathrm{~s}$, slightly water repellent if WDPT ranged from $5 \mathrm{~s}$ to $60 \mathrm{~s}$, and strongly water repellent if WDPT ranged from $60 \mathrm{~s}$ to $600 \mathrm{~s}$ (Bisdom et al. 1993). Error bars depict standard error. Means within a soil depth followed by a different lowercase letter are significantly different $(P<0.05)$.

site roughness likely resulted from rock cover in interspaces and litter under trees. Plot slope angles were uniformly gentle (10$20 \%$ ) across small- and large-plot scales at both sites (Tables 2 and 3).

Soil water repellency under uniformly dry soil conditions was isolated underneath tree canopies at both sites (Fig. 3). Soils were strongly water repellent (WDPT >60 s) at the mineral soil surface immediately underneath tree litter (Fig. 3). The strength of soil water repellency on tree plots generally decreased with increasing soil depth (Fig. 3). Soils on tree plots at Marking Corral were slightly water repellent $(60 \mathrm{~s}>\mathrm{WDPT}>5 \mathrm{~s})$ from 1-4-cm soil depth and were wettable at 5-cm soil depth. The strength of soil water repellency at Onaqui decreased more gradually with soil depth and remained slight at $5-\mathrm{cm}$ depth.

Gravimetric soil water content was low across both sites (Tables 2 and 3). Bulk density was higher $\left(1.35 \mathrm{~g} \cdot \mathrm{cm}^{-3}\right)$ on interspaces than tree $\left(1.08 \mathrm{~g} \cdot \mathrm{cm}^{-3}\right)$ and shrub microsites $\left(1.14 \mathrm{~g} \cdot \mathrm{cm}^{-3}\right)$ at Marking Corral. Bulk density at Onaqui averaged $1.02 \mathrm{~g} \cdot \mathrm{cm}^{-3}$ across interspace and shrub microsites and was $0.82 \mathrm{~g} \cdot \mathrm{cm}^{-3}$ on juniper microsites. Percent sand, silt, and clay contents of surface $(0-2-\mathrm{cm}$ depth) soil samples were $66 \%, 30 \%$, and $4 \%$ at Marking Corral and $56 \%, 37 \%$, and $7 \%$ at Onaqui. Surface soils were coarser $(71 \%$ sand, $25 \%$ silt, $3 \%$ clay) under tree litter on juniper and pinyon coppices than in shrub-interspace areas (62\% sand, $33 \%$ silt, $5 \%$ clay) at Marking Corral. No significant differences in soil texture were observed between microsites at Onaqui.

\section{Small-Plot Rainfall Simulations}

Runoff of applied rainfall was strongly influenced by microsite, and exhibited some between-sites microsite variability ( $\mathrm{Ta}$ ble 4; Figs. 4A and 5A). Runoff was uniformly low for the dry run and increased for the wet run except on Marking Corral pinyon coppices (Table 4). Interspaces produced the most runoff at both sites during the wet run (Table 4; Fig. 4A). Wetrun cumulative runoff was higher for tree plots at Onaqui than Marking Corral and was similar across Onaqui shrub and Marking Corral juniper and shrub plots (Table 4). Pinyon plots retained more than $95 \%$ of applied rainfall and generated the least wet-run runoff (Table 4).

Small-plot runoff rates were higher where litter cover was 0 $30 \%$ (interspaces), consistently low where litter cover ranged from $30 \%$ to $70 \%$ (shrub coppices), and low to moderate where $70-100 \%$ litter cover was underlain by strong waterrepellent soil conditions (tree coppices; Fig. 5A). Small-plot infiltration rates calculated from plots that generated runoff

Table 4. Average rainfall, runoff, infiltration, and sediment response variables for small-plot $\left(0.5 \mathrm{~m}^{2}\right)$ rainfall simulations. Means within a row by run type (dry or wet) followed by a different lowercase letter are significantly different $(P<0.05)$.

\begin{tabular}{|c|c|c|c|c|c|c|c|c|c|c|c|c|c|c|}
\hline \multirow[b]{3}{*}{ Rainfall simulation variable } & \multicolumn{7}{|c|}{ Dry run $\left(64 \mathrm{~mm} \cdot \mathrm{h}^{-1}, 45 \mathrm{~min}\right)$} & \multicolumn{7}{|c|}{ Wet run $\left(102 \mathrm{~mm} \cdot \mathrm{h}^{-1}, 45 \mathrm{~min}\right)$} \\
\hline & \multicolumn{4}{|c|}{ Marking Corral } & \multicolumn{3}{|c|}{ Onaqui } & \multicolumn{4}{|c|}{ Marking Corral } & \multicolumn{3}{|c|}{ Onaqui } \\
\hline & $\begin{array}{l}\text { Inter- } \\
\text { space }\end{array}$ & $\begin{array}{l}\text { Juniper } \\
\text { coppice }\end{array}$ & $\begin{array}{l}\text { Pinyon } \\
\text { coppice }\end{array}$ & $\begin{array}{l}\text { Shrub } \\
\text { coppice }\end{array}$ & $\begin{array}{l}\text { Inter- } \\
\text { space }\end{array}$ & $\begin{array}{l}\text { Juniper } \\
\text { coppice }\end{array}$ & $\begin{array}{l}\text { Shrub } \\
\text { coppice }\end{array}$ & $\begin{array}{l}\text { Inter- } \\
\text { space }\end{array}$ & $\begin{array}{l}\text { Juniper } \\
\text { coppice }\end{array}$ & $\begin{array}{l}\text { Pinyon } \\
\text { coppice }\end{array}$ & $\begin{array}{l}\text { Shrub } \\
\text { coppice }\end{array}$ & $\begin{array}{l}\text { Inter- } \\
\text { space }\end{array}$ & $\begin{array}{l}\text { Juniper } \\
\text { coppice }\end{array}$ & $\begin{array}{l}\text { Shrub } \\
\text { coppice }\end{array}$ \\
\hline Applied rain (mm) & $48 \mathrm{a}$ & $48 \mathrm{a}$ & $47 \mathrm{a}$ & $48 \mathrm{a}$ & $47 \mathrm{a}$ & $47 \mathrm{a}$ & $47 \mathrm{a}$ & $77 \mathrm{a}$ & $77 \mathrm{a}$ & $77 \mathrm{a}$ & $77 \mathrm{a}$ & $76 \mathrm{a}$ & $75 \mathrm{a}$ & $76 \mathrm{a}$ \\
\hline Cumulative runoff (mm) & $16 \mathrm{c}$ & $7 \mathrm{bc}$ & $1 \mathrm{a}$ & $1 \mathrm{a}$ & $7 \mathrm{~b}$ & $10 \mathrm{bc}$ & $0 \mathrm{a}$ & $43 d$ & $12 \mathrm{~b}$ & $2 \mathrm{a}$ & $5 b$ & $39 d$ & $23 \mathrm{c}$ & $6 \mathrm{~b}$ \\
\hline Runoff to rainfall $\left(\mathrm{mm} \cdot \mathrm{mm}^{-1}\right) \times 100 \%$ & $33 \mathrm{c}$ & $14 \mathrm{bc}$ & $2 \mathrm{a}$ & $1 \mathrm{a}$ & $16 \mathrm{~b}$ & $22 \mathrm{bc}$ & $0 \mathrm{a}$ & $56 d$ & $15 \mathrm{~b}$ & $3 a$ & $7 \mathrm{~b}$ & $51 d$ & $31 \mathrm{c}$ & $8 \mathrm{~b}$ \\
\hline Mean infiltration rate $\left(\mathrm{mm} \cdot \mathrm{h}^{-1}\right)^{1}$ & $42 \mathrm{a}$ & $49 a b c$ & $60 \mathrm{c}$ & - & $49 \mathrm{~b}$ & $45 \mathrm{ab}$ & - & $46 \mathrm{a}$ & $85 \mathrm{c}$ & $97 \mathrm{c}$ & $90 \mathrm{c}$ & $50 \mathrm{a}$ & $68 \mathrm{~b}$ & $90 \mathrm{c}$ \\
\hline Minimum infiltration rate $\left(\mathrm{mm} \cdot \mathrm{h}^{-1}\right)^{1}$ & $35 \mathrm{a}$ & $47 \mathrm{bc}$ & $57 \mathrm{c}$ & - & $35 \mathrm{a}$ & $39 a b$ & - & $35 a$ & $79 \mathrm{c}$ & $92 \mathrm{c}$ & $79 \mathrm{c}$ & $41 \mathrm{a}$ & $58 \mathrm{~b}$ & $83 \mathrm{c}$ \\
\hline Final infiltration rate $\left(\mathrm{mm} \cdot \mathrm{h}^{-1}\right)^{1}$ & $35 \mathrm{a}$ & $49 \mathrm{bc}$ & $60 \mathrm{c}$ & - & $35 \mathrm{a}$ & $45 \mathrm{~b}$ & - & $42 \mathrm{a}$ & $87 \mathrm{c}$ & $98 \mathrm{c}$ & $89 \mathrm{c}$ & $41 \mathrm{a}$ & $71 \mathrm{~b}$ & $85 \mathrm{c}$ \\
\hline Cumulative sediment $\left(\mathrm{g} \cdot \mathrm{m}^{-2}\right)^{1}$ & $14 \mathrm{c}$ & $4 \mathrm{bc}$ & $1 \mathrm{a}$ & - & $47 d$ & $27 d$ & - & $52 \mathrm{c}$ & $4 a b$ & $1 \mathrm{a}$ & $4 \mathrm{~b}$ & $207 d$ & $46 \mathrm{c}$ & $38 \mathrm{c}$ \\
\hline Sediment/runoff $\left(\mathrm{g} \cdot \mathrm{m}^{-2} \cdot \mathrm{mm}^{-1}\right)^{1}$ & $0.73 b$ & $0.43 b$ & $0.12 \mathrm{a}$ & - & $4.24 d$ & $2.04 \mathrm{C}$ & - & $1.16 \mathrm{~b}$ & $0.37 \mathrm{a}$ & $0.54 \mathrm{a}$ & $0.39 \mathrm{a}$ & $5.06 \mathrm{~d}$ & $1.96 \mathrm{c}$ & $4.81 \mathrm{~d}$ \\
\hline Percent of plots with runoff & 100 & 60 & 36 & 17 & 69 & 79 & 6 & 100 & 90 & 55 & 58 & 100 & 95 & 79 \\
\hline No. of plots & 22 & 10 & 11 & 12 & 32 & 19 & 18 & 23 & 10 & 11 & 12 & 31 & 19 & 17 \\
\hline
\end{tabular}

${ }^{1}$ Means based solely on plots that generated runoff. 


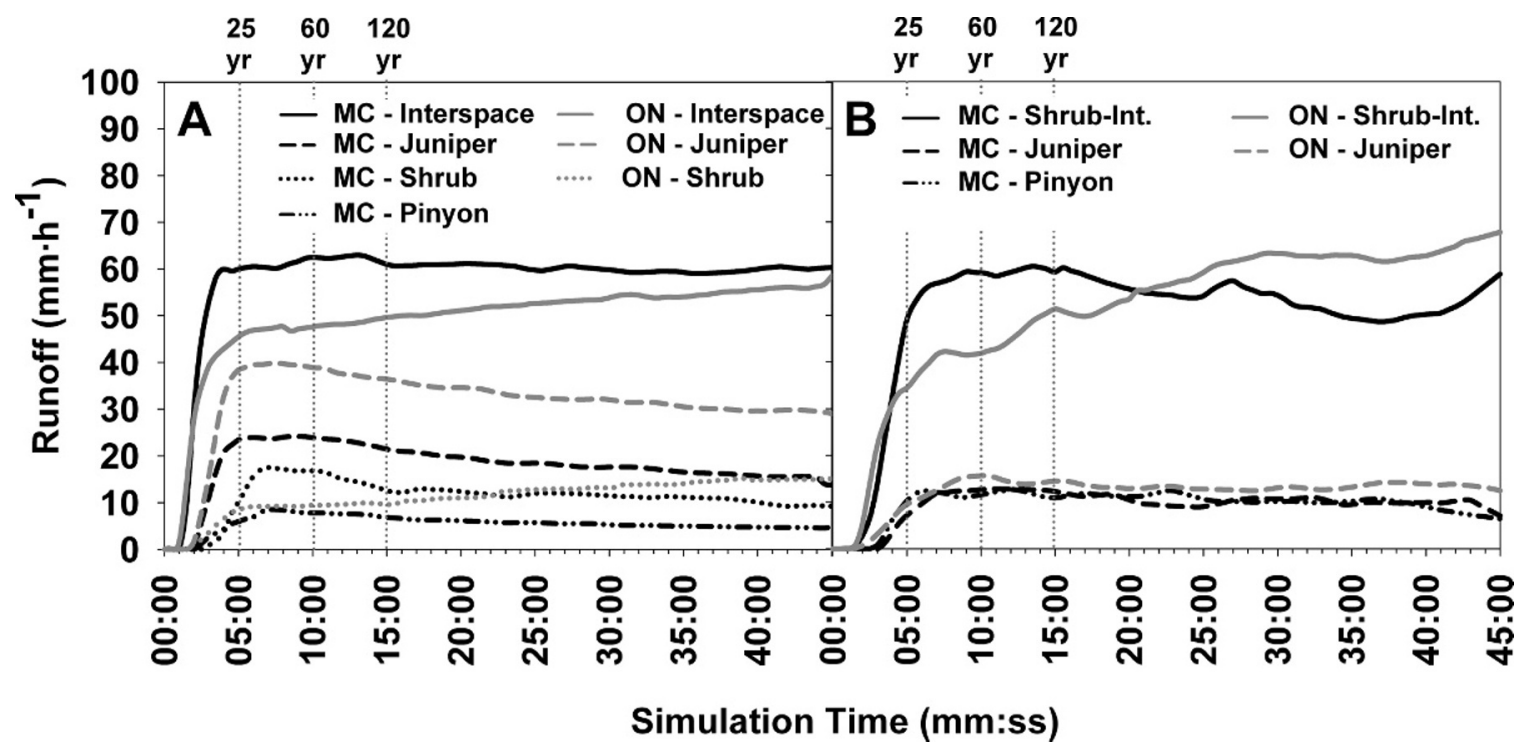

Figure 4. Runoff hydrographs for wet-run $\left(102 \mathrm{~mm} \cdot \mathrm{h}^{-1}, 45 \mathrm{~min}\right)$ rainfall simulation plots that generated runoff within the first 25 min of simulation on $\mathbf{A}$, interspace, juniper, pinyon, and shrub small $\left(0.5 \mathrm{~m}^{2}\right)$ plots and on $\mathbf{B}$, shrub-interspace and tree zones (large plots, $\left.13 \mathrm{~m}^{2}\right)$ at the Marking Corral (MC) and Onaqui (ON) study sites. Vertical dotted lines indicate duration (mm:ss) of the 25-yr, 60-yr, and 120-yr storm events for the applied rainfall intensity.

were nearly equal for dry and wet runs on interspace plots, but increased over $50-60 \%$ across juniper and pinyon plots from the dry to wet run (Table 4). The increased infiltration rates on tree coppices from the dry to wet run indicate a breakdown of surface soil water repellency with increased rainfall and surface wetting. Soil water repellency breakdown is further evident by early runoff peaks and subsequent decreasing runoff rates (increased infiltration, see Pierson et al. 2008b) shown in the juniper and pinyon wet-run hydrographs (Fig. 4A).

Interspace microsites produced the most small-plot sediment yield, but site differences emerged (Table 4). Dry-run soil loss was essentially unmeasureable on shrub and pinyon small plots. Dry-run interspace and juniper sediment yield were equivalent to one another at a site, but were three and six times greater at Onaqui than Marking Corral. Similar trends were observed for dry-run sediment-to-runoff (Table 4), implicating greater erodibility at the Onaqui site. Sediment delivery from the wet run at Marking Corral was nearly equal across juniper, pinyon, and shrub microsites, and was significantly higher on interspace microsites than all other plots (Table 4). Wet-run sediment yields from juniper and shrub microsites at Onaqui were nearly equal to that of Marking Corral interspaces. Sediment-torunoff per unit of rainfall was similar across interspace and shrub plots at Onaqui, but was higher than measured on the same microsites at Marking Corral. Site erodibility differences are further implicated in a plot of wet-run sediment yield versus percent litter cover (Fig. 5B). Wet-run sediment yield versus percent litter cover was generally higher for Onaqui interspace and juniper plots than measured at Marking Corral. The between-sites variability in sediment yield from juniper plots is

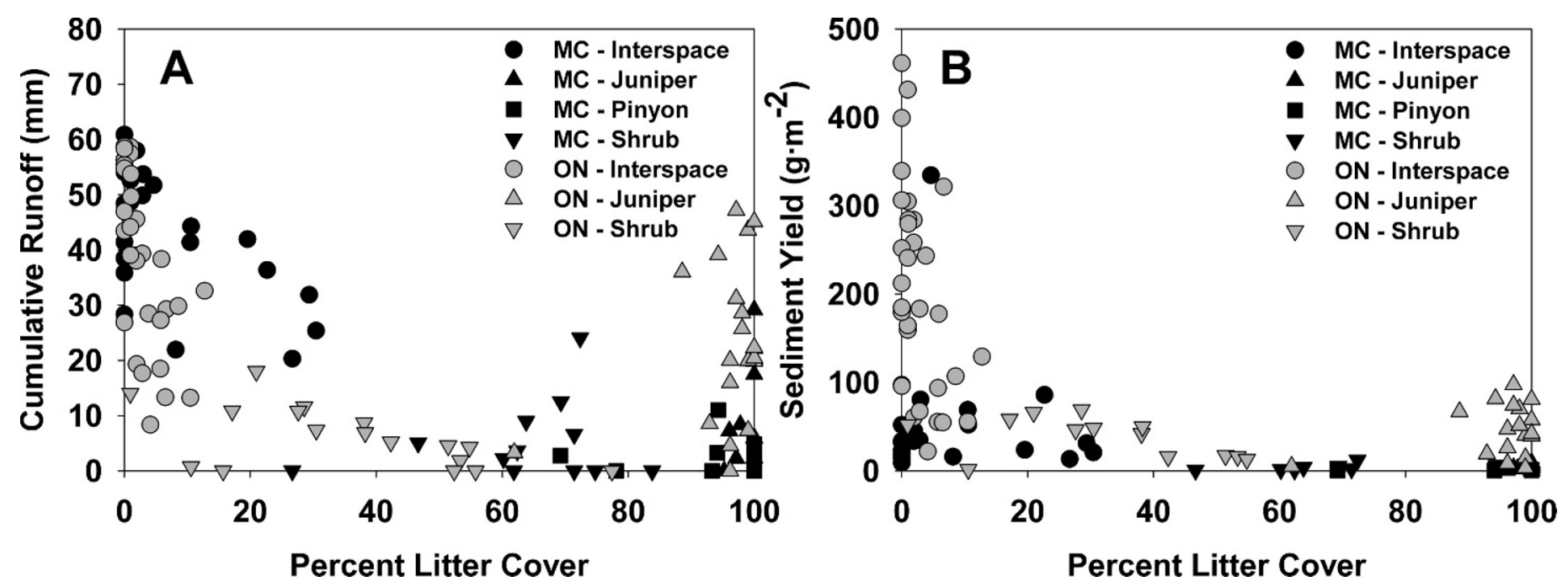

Figure $\mathbf{5}$. Cumulative runoff $\mathbf{A}$, and sediment yield $\mathbf{B}$, versus percent litter cover as measured on small $\left(0.5 \mathrm{~m}^{2}\right)$ rainfall simulation plots during the wet run (102 mm $\left.\cdot \mathrm{h}^{-1}, 45 \mathrm{~min}\right)$. Data points are shown for interspace, juniper, pinyon, and shrub coppice microsites at the Marking Corral (MC) and Onaqui (ON) study sites. 
Table 5. Average rainfall, runoff, infiltration, sediment, and wetting-depth response variables for large-plot (13 $\left.\mathrm{m}^{2}\right)$ rainfall simulations. Means within a row by run type (dry or wet) followed by a different lowercase letter are significantly different $(P<0.05)$.

\begin{tabular}{|c|c|c|c|c|c|c|c|c|}
\hline \multirow[b]{3}{*}{ Rainfall simulation variable } & \multicolumn{4}{|c|}{ Dry run $\left(64 \mathrm{~mm} \cdot \mathrm{h}^{-1}, 45 \mathrm{~min}\right)$} & \multicolumn{4}{|c|}{ Wet run $\left(102 \mathrm{~mm} \cdot \mathrm{h}^{-1}, 45 \mathrm{~min}\right)$} \\
\hline & \multicolumn{2}{|c|}{ Marking Corral } & \multicolumn{2}{|c|}{ Onaqui } & \multicolumn{2}{|c|}{ Marking Corral } & \multicolumn{2}{|l|}{ Onaqui } \\
\hline & $\begin{array}{c}\text { Shrub-interspace } \\
\text { zone }\end{array}$ & $\begin{array}{l}\text { Tree } \\
\text { zone }\end{array}$ & $\begin{array}{c}\text { Shrub-interspace } \\
\text { zone }\end{array}$ & $\begin{array}{l}\text { Tree } \\
\text { zone }\end{array}$ & $\begin{array}{c}\text { Shrub-interspace } \\
\text { zone }\end{array}$ & $\begin{array}{l}\text { Tree } \\
\text { zone }\end{array}$ & $\begin{array}{l}\text { Shrub-interspace } \\
\text { zone }\end{array}$ & $\begin{array}{l}\text { Tree } \\
\text { zone }\end{array}$ \\
\hline Applied rain (mm) & $45 \mathrm{a}$ & $46 a b$ & $49 a b$ & $50 \mathrm{~b}$ & $81 \mathrm{a}$ & $81 \mathrm{a}$ & $87 \mathrm{ab}$ & $93 \mathrm{~b}$ \\
\hline Cumulative runoff (mm) & $11 \mathrm{~b}$ & $1 \mathrm{a}$ & $5 \mathrm{a}$ & $1 \mathrm{a}$ & $38 \mathrm{~b}$ & $4 \mathrm{a}$ & $39 \mathrm{~b}$ & $9 \mathrm{a}$ \\
\hline Runoff-to-rainfall $\left(\mathrm{mm} \cdot \mathrm{mm}^{-1}\right) \times 100 \%$ & $24 \mathrm{~b}$ & $3 a$ & $10 \mathrm{a}$ & $2 \mathrm{a}$ & $47 \mathrm{~b}$ & $5 \mathrm{a}$ & $44 \mathrm{~b}$ & $10 \mathrm{a}$ \\
\hline Mean infiltration rate $\left(\mathrm{mm} \cdot \mathrm{h}^{-1}\right)^{1}$ & $46 \mathrm{a}$ & $53 \mathrm{ab}$ & $58 \mathrm{~b}$ & $64 \mathrm{c}$ & $57 \mathrm{a}$ & $102 \mathrm{~b}$ & $66 \mathrm{a}$ & $112 b$ \\
\hline Minimum infiltration rate $\left(\mathrm{mm} \cdot \mathrm{h}^{-1}\right)^{1}$ & $42 \mathrm{a}$ & $52 \mathrm{ab}$ & $47 \mathrm{a}$ & $61 \mathrm{~b}$ & $50 \mathrm{a}$ & $100 \mathrm{~b}$ & $49 \mathrm{a}$ & $103 \mathrm{~b}$ \\
\hline Final infiltration rate $\left(\mathrm{mm} \cdot \mathrm{h}^{-1}\right)^{1}$ & $43 \mathrm{a}$ & $54 \mathrm{bc}$ & $47 \mathrm{ab}$ & $62 c$ & $60 \mathrm{a}$ & $105 \mathrm{~b}$ & $55 \mathrm{a}$ & $111 \mathrm{~b}$ \\
\hline Cumulative sediment $\left(\mathrm{g} \cdot \mathrm{m}^{-2}\right)^{1}$ & $45 \mathrm{~b}$ & $18 a b$ & $37 a b$ & $13 \mathrm{a}$ & $222 \mathrm{~b}$ & $36 \mathrm{a}$ & 296 b & $66 \mathrm{a}$ \\
\hline Sediment/runoff $\left(\mathrm{g} \cdot \mathrm{m}^{-2} \cdot \mathrm{mm}^{-1}\right)^{1}$ & $4.11 \mathrm{a}$ & $10.35 b$ & $12.73 \mathrm{~b}$ & $14.18 \mathrm{~b}$ & $5.75 \mathrm{a}$ & $6.13 \mathrm{a}$ & $7.64 \mathrm{a}$ & $7.22 \mathrm{a}$ \\
\hline Percent wet at 6-cm depth & - & - & - & - & $100 \mathrm{~b}$ & $85 \mathrm{a}$ & $99 \mathrm{~b}$ & $87 \mathrm{a}$ \\
\hline Percent wet at $10-\mathrm{cm}$ depth & - & - & - & - & $100 \mathrm{~b}$ & $88 \mathrm{a}$ & $99 \mathrm{~b}$ & $87 \mathrm{a}$ \\
\hline Percent wet at 20-cm depth & - & - & - & - & $93 a b$ & $94 \mathrm{~b}$ & $98 \mathrm{~b}$ & $87 \mathrm{a}$ \\
\hline Percent of plots with runoff & 100 & 50 & 94 & 78 & 100 & 67 & 100 & 100 \\
\hline No. of plots & 11 & 12 & 17 & 18 & 10 & 9 & 17 & 16 \\
\hline
\end{tabular}

${ }^{1}$ Means based solely on plots that generated runoff.

partially explained by similar between-sites variability in runoff (transport potential) from juniper plots (Table 4); site differences in wet-run runoff from interspaces were indistinguishable (Table 4).

\section{Large-Plot Rainfall Simulations}

Large-plot runoff responses were greater from shrub-interspace zones than tree zones across all plots during the wet run, and dry-run microsite differences occurred at Marking Corral solely (Table 5). Final dry-run infiltration rates were higher for tree zones than shrub-interspace zones at each site and were comparable between Marking Corral tree plots and all Onaqui plots. Microsite differences in dry-run average and minimum infiltration rates were significant for Onaqui only. Wet-run runoff and the runoff per unit of rainfall were consistently higher from shrub-interspaces than tree zones across both sites (Table 5; Fig. 4B). Wet-run infiltration rates on shrub-interspace zones were approximately within the range of those measured across all plots during the dry run (Table 5). Infiltration rates on tree zones increased by an average of $80 \%$ between the dry to wet runs. We attribute increased infiltration rates from the dry to wet runs on large tree plots to the higher rainfall application rate (water availability), reduced soil water repellency, and formation of more uniform wet conditions as reported for small rainfall plots.

Large-plot sediment yield was notably influenced by runoff rates, and shrub-interspaces generated significantly more erosion than tree zones (Table 5; Fig. 6). Dry-run cumulative sediment yield was similar across Marking Corral tree zones and all Onaqui plots due to minimal dry-run runoff (Table 5). Dry-run cumulative sediment yield was comparable across microsites at Marking Corral even though sediment-to-runoff ratios were significantly higher for tree zones; the statistically similar dry-run cumulative sediment across microsites is associated with greater dry-run runoff from shrub-interspace plots (Table 5). Sediment-to-runoff ratios were consistent across all plots for the wet run, but sediment yield was fivefold to sixfold greater for shrub-interspace than tree zones at both sites (Table 5). Nearly equal magnitude differences were measured for runoff from shrub-interspace and tree zones during the wet run at both sites (Table 5).

Large-plot wet-run runoff and sediment yield were moderately to strongly correlated with percent rock, percent litter cover, and the combined percentages of bare soil and rock cover (Fig. 7). Runoff rates were low (below $30 \mathrm{~mm} \cdot \mathrm{h}^{-1}$ ) where rock cover ranged from $0 \%$ to $30 \%$ (Fig. $7 \mathrm{~A}$ ) and litter cover exceeded $60 \%$ (Fig. 7B). Runoff increased exponentially

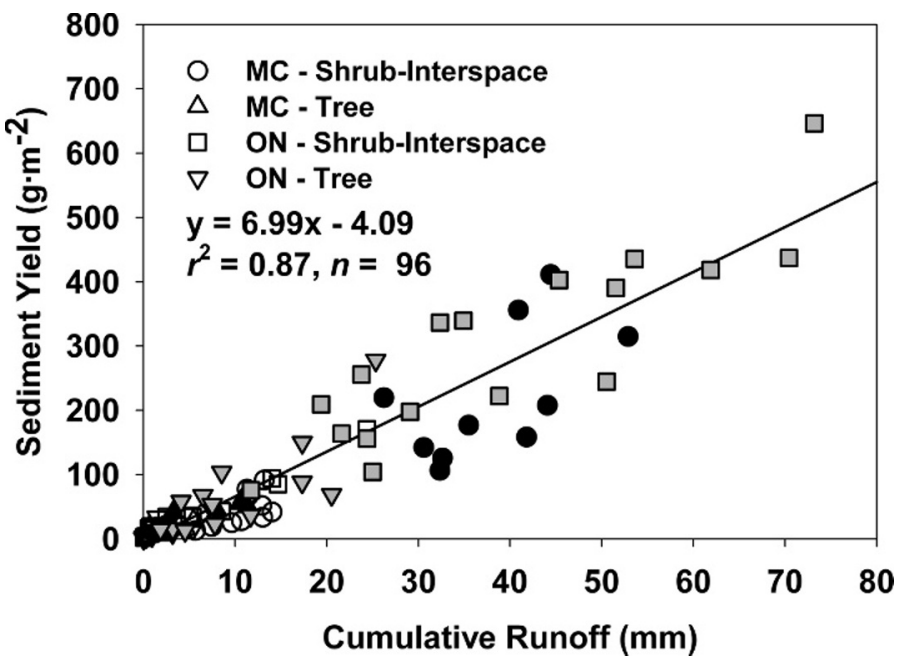

Figure 6. Cumulative runoff versus sediment yield measured on shrubinterspace and tree zone large $\left(13 \mathrm{~m}^{2}\right)$ rainfall simulation plots at the Marking Corral (MC) and Onaqui (ON) study sites. Shaded symbols represent wet-run rainfall simulations $\left(102 \mathrm{~mm} \cdot \mathrm{h}^{-1}, 45 \mathrm{~min}\right)$ and unshaded symbols depict dry-run simulations (64 mm $\left.\cdot \mathrm{h}^{-1}, 45 \mathrm{~min}\right)$. Solid line and $r^{2}$ shown depict linear correlation of runoff and sediment yield across both application rates. 

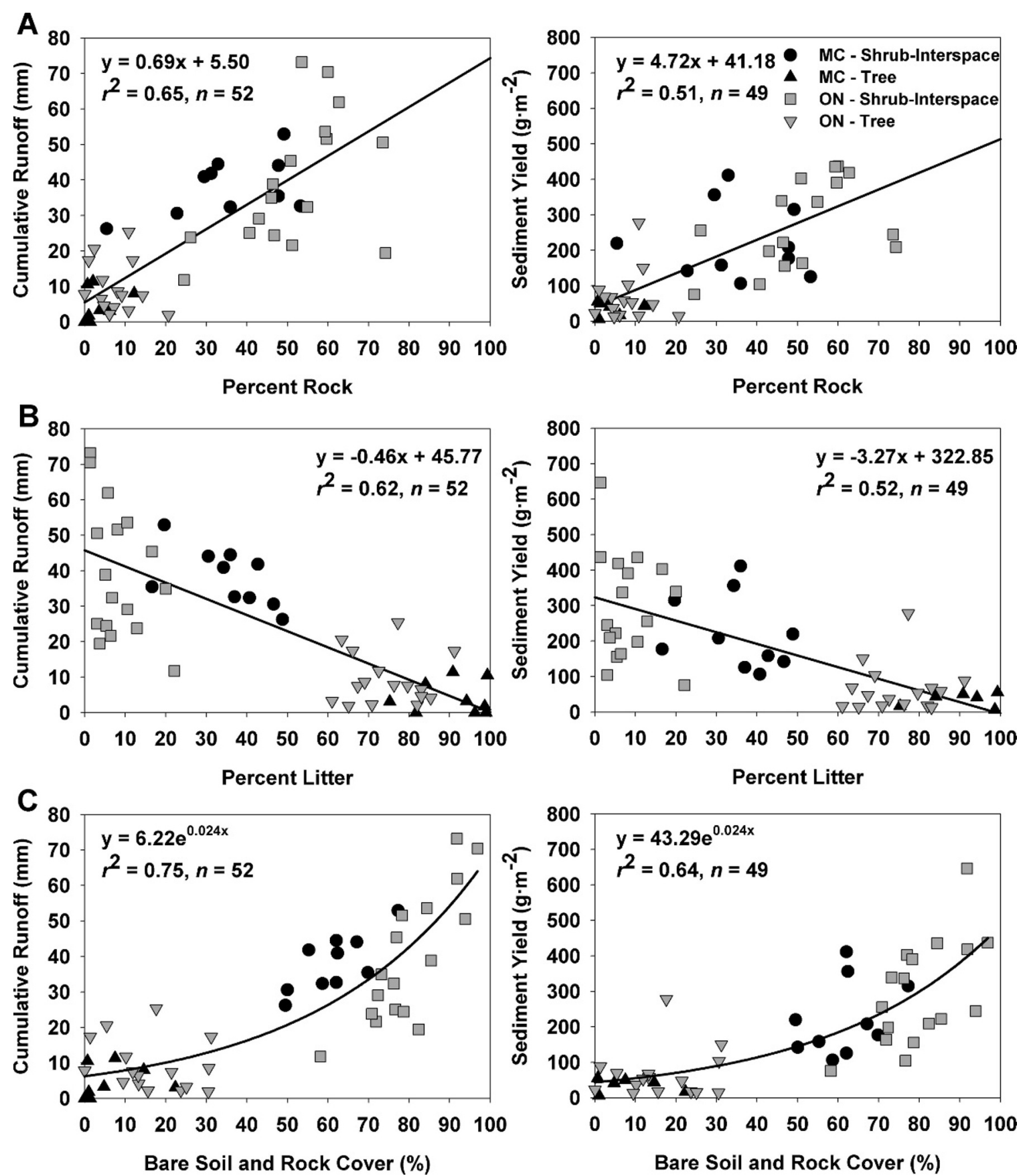

Figure 7. Correlation of cumulative runoff and sediment yield with $\mathbf{A}$, rock cover, B, litter cover, and $\mathbf{C}$, percent bare soil and rock cover measured on large $\left(13 \mathrm{~m}^{2}\right.$ ) wet-run rainfall simulation (102 $\left.\mathrm{mm} \cdot \mathrm{h}^{-1}, 45 \mathrm{~min}\right)$ plots at the Marking Corral (MC) and Onaqui (ON) study sites. Legend shown for percent rock (A) applies to all graphs.

$\left(r^{2}=0.75\right)$ where percent bare soil and rock cover exceeded $50 \%$ (Fig. 7C). Sediment yield increased linearly as runoff rates increased beyond $15-20 \mathrm{~mm} \cdot \mathrm{h}^{-1}$ (Fig. 6), and relationships between sediment yield and percent rock cover, percent litter cover, and percent bare soil and rock were consistent, although weaker, with those observed for runoff (Fig. 7). These relationships show clear separation in wet-run runoff rates and sediment yield between shrub-interspace and tree zones and indicate the differences in microsite response are related to microsite differences in the amount of litter, bare soil, and rock cover.
The percent area wet to $6-\mathrm{cm}, 10-\mathrm{cm}$, and $20-\mathrm{cm}$ soil depths was high $(>85 \%)$ across all plots (Table 5), but was significantly greater for shrub-interspace than tree plots. Storage of water in tree litter layers probably reduced water available for infiltration, but shrub interception on shrub interspaces likely offset a portion of litter storage observed in tree zones. We therefore partially attribute the microsite differences in soil profile wetted area to the presence of soil water repellency (Fig. 3). The near-saturation conditions of over $87 \%$ of the soil profile to a depth of $20 \mathrm{~cm}$ across all plots 
Table 6. Concentrated flow characteristics by flow release rate. Total rill area width (TRAW) represents the total width between the outermost edges of the outermost flow paths. Means within a column by release rate followed by a different lowercase letter are significantly different $(P<0.05)$.

\begin{tabular}{|c|c|c|c|c|c|c|c|c|c|c|c|c|}
\hline Site & Microsite & $\begin{array}{l}\text { Release } \\
\text { rate } \\
\left(\mathrm{L} \cdot \mathrm{min}^{-1}\right)\end{array}$ & $\begin{array}{l}\text { Cumulative } \\
\text { runoff } \\
\text { (L) }\end{array}$ & $\begin{array}{c}\text { Average } \\
\text { runoff } \\
\left(\mathrm{L} \cdot \mathrm{min}^{-1}\right)\end{array}$ & $\begin{array}{l}\text { Cumulative } \\
\text { sediment } \\
(\mathrm{g})^{1}\end{array}$ & $\begin{array}{c}\text { Average } \\
\text { sediment } \\
\text { concentration } \\
\left(\mathrm{g} \cdot \mathrm{L}^{-1}\right)^{1}\end{array}$ & $\begin{array}{l}\text { Flow } \\
\text { width } \\
(\mathrm{cm})^{1}\end{array}$ & $\begin{array}{l}\text { Flow } \\
\text { depth } \\
(\mathrm{cm})^{1}\end{array}$ & $\begin{array}{l}\text { TRAW } \\
(\mathrm{cm})^{1}\end{array}$ & $\begin{array}{c}\text { Flow } \\
\text { velocity } \\
\left(\mathrm{m} \cdot \mathrm{s}^{-1}\right)^{1}\end{array}$ & $\begin{array}{c}\text { No. } \\
\text { of rills }{ }^{1}\end{array}$ & $\begin{array}{c}\text { Percent of } \\
\text { plots with } \\
\text { runoff }\end{array}$ \\
\hline Marking & Shrub-interspace & 15 & $51.2 \mathrm{~b}$ & $6.0 \mathrm{~b}$ & $26.2 \mathrm{a}$ & $0.8 \mathrm{a}$ & $57.9 \mathrm{~b}$ & $0.5 \mathrm{a}$ & $135.4 \mathrm{~b}$ & $0.06 \mathrm{a}$ & $2.0 \mathrm{~b}$ & 100 \\
\hline \multirow[t]{5}{*}{ Corral } & zone & 30 & $173.4 \mathrm{~b}$ & $20.4 \mathrm{~b}$ & $334.2 \mathrm{~b}$ & $1.8 \mathrm{a}$ & $62.3 \mathrm{bc}$ & $0.9 \mathrm{a}$ & $165.1 \mathrm{~b}$ & $0.08 \mathrm{~b}$ & $2.3 \mathrm{~b}$ & 100 \\
\hline & & 45 & $290.3 b$ & $34.2 \mathrm{~b}$ & $956.7 \mathrm{~b}$ & $3.1 \mathrm{~b}$ & $62.9 a b$ & $0.9 \mathrm{a}$ & $163.7 \mathrm{~b}$ & $0.12 b$ & $2.3 \mathrm{~b}$ & 100 \\
\hline & Tree zone & 15 & $3.5 \mathrm{a}$ & $0.4 \mathrm{a}$ & - & - & - & - & - & - & - & 17 \\
\hline & & 30 & $78.3 \mathrm{a}$ & $9.2 \mathrm{a}$ & $120.7 \mathrm{a}$ & $1.5 \mathrm{a}$ & $33.8 \mathrm{a}$ & $0.6 \mathrm{a}$ & 82.9 a & $0.04 \mathrm{a}$ & $1.5 \mathrm{a}$ & 83 \\
\hline & & 45 & $221.2 \mathrm{a}$ & $26.0 \mathrm{a}$ & $120.2 \mathrm{a}$ & $0.8 \mathrm{a}$ & $57.9 \mathrm{ab}$ & $0.8 \mathrm{a}$ & $124.4 a b$ & $0.04 \mathrm{a}$ & $1.8 a b$ & 100 \\
\hline \multirow[t]{6}{*}{ Onaqui } & Shrub-interspace & 15 & $70.4 \mathrm{c}$ & $8.3 \mathrm{c}$ & $200.3 b$ & $2.9 \mathrm{~b}$ & $58.3 \mathrm{~b}$ & $0.5 \mathrm{a}$ & $90.7 \mathrm{a}$ & $0.07 \mathrm{a}$ & $1.6 \mathrm{ab}$ & 100 \\
\hline & zone & 30 & $174.6 \mathrm{~b}$ & $20.5 b$ & $605.3 \mathrm{c}$ & $3.5 \mathrm{~b}$ & $67.6 \mathrm{c}$ & $0.7 \mathrm{a}$ & $124.5 \mathrm{~b}$ & $0.11 \mathrm{~b}$ & $1.6 \mathrm{a}$ & 100 \\
\hline & & 45 & $292.3 \mathrm{~b}$ & $34.4 \mathrm{~b}$ & $1431.4 \mathrm{c}$ & $4.9 \mathrm{c}$ & $67.1 \mathrm{~b}$ & $0.8 \mathrm{a}$ & $131.3 a b$ & $0.17 \mathrm{c}$ & $1.8 \mathrm{ab}$ & 100 \\
\hline & Tree zone & 15 & $11.4 \mathrm{a}$ & $1.3 \mathrm{a}$ & $59.6 \mathrm{a}$ & $2.4 \mathrm{~b}$ & $23.3 \mathrm{a}$ & $0.7 \mathrm{a}$ & $48.5 \mathrm{a}$ & $0.05 \mathrm{a}$ & $1.1 \mathrm{a}$ & 44 \\
\hline & & 30 & $65.9 \mathrm{a}$ & $7.8 \mathrm{a}$ & $224.6 \mathrm{ab}$ & $2.7 \mathrm{~b}$ & $40.0 a b$ & $0.9 \mathrm{a}$ & $72.6 \mathrm{a}$ & $0.07 a b$ & $1.1 \mathrm{a}$ & 94 \\
\hline & & 45 & $203.2 \mathrm{a}$ & $23.9 \mathrm{a}$ & 801.2 b & $3.4 \mathrm{bc}$ & $42.6 \mathrm{a}$ & $0.9 \mathrm{a}$ & $113.7 \mathrm{a}$ & $0.14 \mathrm{bc}$ & $1.4 \mathrm{a}$ & 100 \\
\hline
\end{tabular}

${ }^{1}$ Means based solely on plots that generated runoff.

after the wet run indicates rainfall was able to infiltrate through portions of the strongly water-repellent layer on tree plots. The actual flow paths through the profile were not specifically investigated, but are assumed to result from reduced soil water repellency with increased wetting and infiltration through macropores into wettable soils at depth (see Meeuwig 1971; DeBano 1981; Ritsema et al. 1993; Ritsema and Dekker 1994, 1995; Pierson et al. 2008b).

\section{Concentrated Flow Simulations}

Concentrated flow runoff and erosion were greater from shrubinterspace than tree zones at both study sites, but some site differences were observed for concentrated flow processes (Table 6). Cumulative runoff, average runoff rate, and cumulative sediment yield were consistently higher from shrubinterspace than tree zones (Table 6). Site-specific microsite differences in the sediment concentration of runoff were significant for Marking Corral, release rate $45 \mathrm{~L} \cdot \mathrm{min}^{-1}$, solely (Table 6). This suggests the microsite differences in sediment yield were related more to runoff rates than differences in microsite erodibility. Sediment concentrations were higher at Onaqui than Marking Corral, whereas microsite runoff rates were consistent across sites, resulting in higher cumulative sediment yield from Onaqui shrub-interspace plots for all release rates (Table 6). The significant differences in concentrated flow erosion between sites for shrub-interspace zones are consistent with interspace wet-run erosion results (Table 4), and suggest site differences in erodibility from concentrated flow processes.

The differences in measured concentrated flow runoff between microsites at both sites were mostly related to wider flow paths on shrub-interspace than tree plots (Table 6). Wider flow paths were measured in shrub-interspace zones as released flow spread out over the less-permeable rock-armored ground surface; concentrated flow released in tree zones infiltrated into the litter, resulting in narrow surface-flow paths. Concentrated flow velocity across the ground surface was lowest on Marking Corral tree plots, but was similar across Marking Corral shrub- interspace and Onaqui plots (Table 6). The depth of concentrated flow ranged from $0.5 \mathrm{~cm}$ to nearly $1 \mathrm{~cm}$ across all plots and the number of flow paths was generally consistent across plots and release rates (Table 6).

\section{Runoff and Erosion Across Plot Scales}

Erosion was amplified with increasing plot scale even though runoff decreased or remained constant across plot scales (Fig. 8). Large-plot scale wet-run runoff from shrub-interspace zones and from Marking Corral tree zones was similar to that from interspace and tree microsites, respectively, at the smallplot scale (Fig. 8A). Wet-run runoff from Onaqui tree zones at the large-plot scale was less than measured on small tree plots (Fig. 8A). Shrub-interspaces at Marking Corral and Onaqui generated approximately 4 -fold and 1.5 -fold more wet-run erosion, respectively, at the large-plot scale than small-plot interspaces without shrub cover, despite the runoff-plot scale relationships (Fig. 8B). Erosion from tree zones increased with increasing plot scale solely at Marking Corral (Fig. 8B). Onaqui large tree plots generated equivalent erosion to small tree plots, even though runoff was lower at the large-plot scale (Fig. 8).

\section{DISCUSSION}

The discretely different hydrologic behavior of intercanopy (shrub-interspace zones) and tree coppice areas in this study and others from pinyon and juniper woodlands (Roundy et al. 1978; Reid et al. 1999; Pierson et al. 2007a; Petersen and Stringham 2008) suggest the hydrologic impact of woodland encroachment on sagebrush steppe likely depends on its effect on the expanse of interspace and bare ground within the intercanopy. Tree coppices across spatial scales in this study represented hydrologically stable, resource-conserving components of the landscape (Tables 4 and 5; Fig. 8). High-intensity $\left(102 \mathrm{~mm} \cdot \mathrm{h}^{-1}\right)$ artificial rainfall on interspace small plots and shrub-interspace zones generated approximately 2-10 times 

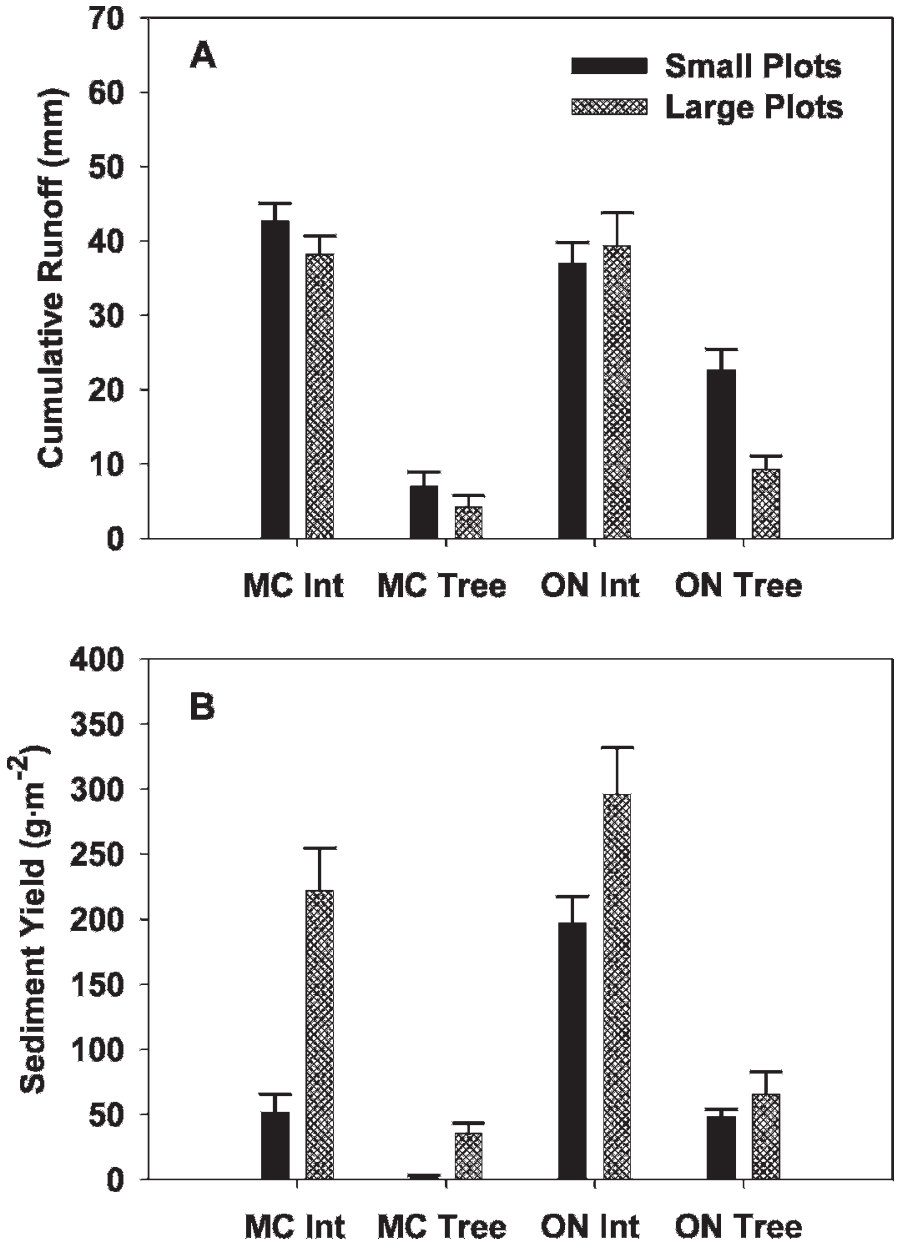

Figure 8. Measured (A) cumulative runoff $(\mathrm{mm})$ and $(B)$ sediment yield $\left(\mathrm{g} \cdot \mathrm{m}^{-2}\right)$ from wet-run rainfall simulations $\left(102 \mathrm{~mm} \cdot \mathrm{h}^{-1}, 45 \mathrm{~min}\right)$ on interspace (Int) and tree small plots $\left(0.5 \mathrm{~m}^{2}\right)$ and shrub-interspace (Int) and tree large plots $\left(13 \mathrm{~m}^{2}\right)$ at the Marking Corral (MC) and Onaqui (ON) study sites. Error bars represent standard error.

more runoff and 4-20 times more erosion than areas underneath tree canopies (Tables 4 and 5). Roundy et al. (1978) reported 1.5 -fold to 4 -fold lower infiltration rates and 14 -fold to 19 -fold greater erosion on small $\left(0.5-\mathrm{m}^{2}\right)$ interspace plots relative to juniper and pinyon coppices. Reid et al. (1999) measured runoff and erosion from natural rainfall events on small (1-2 $\mathrm{m}^{2}$ ) plots of tree coppice, vegetated-intercanopy, and bare-intercanopy areas in a New Mexico pinyon-juniper woodland. Bare-intercanopy runoff was two and four times greater than measured on vegetated-intercanopy and tree canopy plots; bare-intercanopy erosion was 3 and 25 times that of the vegetated-intercanopy and tree canopy areas. Petersen and Stringham (2008) found infiltration rates under artificial rainfall $\left(0.5-\mathrm{m}^{2}\right.$ plots $)$ on intercanopy areas of an Oregon, USA, juniper woodland increased with decreasing juniper cover and increasing shrub cover. Intercanopy erosion in the same study was greater from hillslopes with high juniper cover $(23-32 \%)$ and low shrub cover $(<5 \%)$ than juniper-free controls. Pierson et al. (2007a) reported runoff and erosion rates under artificial rainfall $\left(32.5-\mathrm{m}^{2}\right.$ plots) were 14 and 85 times higher from intercanopy areas of a juniper woodland than from an adjacent site where trees were removed $10 \mathrm{yr}$ earlier; concentrated flow erosion rates were 15 times higher from woodland intercanopy plots than plots on juniper-free hillslopes (Pierson et al. 2007a). Pierson et al. (2007a) attributed greater runoff and erosion on juniper-dominated than juniper-free hillslopes to low soil surface cover of herbaceous plants and litter as well as large interconnected patches of bare soil.

The positive erosion-plot scale relationships (Fig. 8B) and site characteristics (Table 1; Fig. 2) observed in this study indicate the soils at both study sites are highly erodible and are vulnerable to accelerated runoff and erosion with increasing woodland infill and expansion. In a contrasting pinyon-juniper woodland study, Reid et al. (1999) found runoff and erosion during convective rainfall events were lower from $1-\mathrm{m}$-wide by 8-m-long intercanopy plots than smaller, 1- $\mathrm{m}^{2}$, intercanopy plots. Reid et al. (1999) attributed the differences to water and sediment storage (conservation) on the larger plots and hypothesized the differences represent run-on and sediment transfer from bare soil to vegetated intercanopy locations. Davenport et al. (1998) suggested the conversion from resource-conserving, observed in the Reid et al. (1999) study, to the rapidly degraded state, as observed in this study, is predicated on soil loss potential and ground cover levels. We measured an exponential increase in runoff and sediment yield with increasing bare soil and rock cover (Fig. 7C). The results demonstrate 10-35\% litter cover and 5-20\% shrub canopy cover offered little protection against rainsplash and overland flow erosion in the shrub-interspace zone for the soils studied. The 35-50\% rock cover (Fig. 2) on and positive erosion-plot scale relationships (Fig. $8 \mathrm{~B}$ ) for shrub-interspace zones across sites imply significant redistribution of soil resources occur on these landscapes over at least $10-30 \mathrm{~m}^{2}$ areas (single to paired large-plot area). Groupings of shrub skeletons (Table 1) and extensive bare ground in shrub-interspaces at both sites (Fig. 2) suggest woodland encroachment is negatively influencing vegetation and ground cover recruitment (Miller et al. 2005; Tausch and Hood 2007; Miller et al. 2008). Progression to Phase III encroachment would likely result in greater shrubinterspace bare ground and reductions of shrub and herbaceous cover (Miller et al. 2005; Tausch and Hood 2007; Miller et al. 2008). Runoff and erosion would therefore be expected to increase from shrub-interspace zones, at least over the spatial scales measured in this study.

Runoff and sediment yield across scales and processes were primarily influenced by the presence, quantity, and type of ground cover (Fig. 7). Rapid runoff generation and erosion were produced from intercanopy areas that exhibited a high percentage of bare soil and rock cover, at both the small and large-plot scales (Tables 2-6; Figs. 2 and 4). Canopy and litter cover on shrub and tree coppices offered some protection from rainsplash effects (Fig. 5B), provided storage of rainfall, and contributed to aggregate stability (Table 2). Strongly waterrepellent soils were observed under dense tree litter mats (Fig. 3), but water storage and surface protection provided by the litter mitigated the effects of soil water repellency on runoff and erosion. Reduced water repellency during rainfall simulation was partially responsible, along with greater water availability and storage in litter, for the doubling of infiltration rates on tree coppices during the wet runs (Tables 4 and 5). Concentrated flow released in tree zones infiltrated into the 
litter layer, whereas flow releases on shrub-interspaces were forced to spread out (Table 6) because of bare soil and rock cover resistances to infiltration. The exposure of the soil surface to flowing water on shrub-interspaces yielded higher concentrated flow runoff rates and greater sediment detachment and transport than observed in tree zones (Tables 5 and 6; Pierson et al. 2008b). The rainfall simulation results suggest shrubinterspace zones at both sites are capable of generating 3-6 times more runoff (Fig. 4B) and greater sediment yield than tree zones from a 5-15-min duration event of $102 \mathrm{~mm} \cdot \mathrm{h}^{-1}$ intensity. This storm for the sites in this study has a return interval of 25-120 yr (Bonnin et al. 2006). For the study sites investigated here, it appears a litter and vegetative basal cover in excess of $30-50 \%$ are needed to stabilize soil aggregates and mitigate high runoff and erosion rates from rainsplash, sheet flow, and concentrated flow processes. These cover requirements are consistent with others reported for rangeland sites (Gifford 1985).

The differences in site erodibility between the two sites in this study highlight the importance of considering site-specific soil properties when evaluating potential erosional responses to woodland encroachment. Erosion (Tables 4-6) from rainsplash, sheet flow, and concentrated flow processes was generally greater at Onaqui than Marking Corral, even though ground cover and understory vegetation (Table 2; Fig. 2) differences were minor. Site differences in erosion were most pronounced for small-plot rainfall simulations (Table 4) and for concentrated flow simulations on shrub-interspaces (Table 6). The higher sediment-torunoff ratios (Tables 4 and 5) and sediment concentrations (Table 6) observed at Onaqui indicate that site is more vulnerable to amplified soil loss associated with decreasing ground cover following woodland encroachment.

Of the rangeland health measures investigated in this study, ground cover and aggregate stability were the best indicators of the hydrologic and erosional response. Runoff and erosion were both well correlated with percent bare soil and rock cover (Fig. 7), and aggregate stability (Table 2) measures were consistent with erosional responses. Runoff and erosion were poorly correlated with basal and canopy gap data. Large gaps between plant bases and canopies were measured in tree zones and shrub-interspaces (Table 3). However, litter cover on the ground surface between plants and canopies in tree-zone gaps reduced raindrop impact and mitigated runoff and erosion. Isolating gap-hydrology relationships to shrub-interspace plots improved correlations, but the effect was not significant. These results indicate the gap measures for hydrological purposes should consider whether the ground surface is bare, rock covered, or litter covered. Gap data as collected in this study may be a good indicator of hydrologic and erosional response where bare ground is extensive or litter cover is negligible (i.e., postfire or more arid climates).

\section{MANAGEMENT IMPLICATIONS}

This study documents the high spatial variability in hydrologic function of tree and shrub-interspace zones after woodland encroachment into sagebrush steppe, and provides a basis for predicting amplified runoff and erosion as a function of intercanopy area. Sediment yield from the two woodland sites
(25\% tree cover) in this study was highly affected by runoff rates and surface protection afforded by litter. Relative runoff rates for a given rainfall intensity and initial soil moisture were also affected by ground and canopy cover and soil water repellency. Litter cover greater than $60 \%$ provided greater aggregate stability, higher infiltration rates, and lower runoff and erosion from a high-intensity, low-return-interval storm, even with the presence of strongly water-repellent soils. Quasithresholds for amplified runoff and erosion were observed where combined rock cover and bare soil was greater than $50 \%$, and the threshold was bounded with low litter cover and high runoff and erosion rates on shrub-interspace zones and high litter cover and low erosion rates on tree plots. Runoff and erosion were more related to the type and presence of ground cover within canopy and basal gaps than gap size. The measured runoff and erosion rates document relative hydrologic stability underneath tree canopies and that shrubinterspaces exhibit the higher water and soil loss vulnerability as tree density reduces intercanopy ground cover.

The results suggest that larger-scale hydrologic impacts of woodland encroachment cannot merely be aggregated from small-scale microsite effects, but must also consider the spatial arrangement of microsites with increased tree dominance. An increase in the expanse and connectivity of bare soil patches and rock cover with expanding tree dominance poses a significant rangeland health concern relative to soil redistribution. Woodland encroachment effects on watershed scale runoff and erosion cannot be inferred from the spatial scales measured in this study; however, the site characteristics and positive erosion-plot scale relationships measured imply significant redistribution of soil resources occur where tree encroachment facilitates vegetative coarsening. Indicators for vegetative change are beyond the scope of this article, but should be considered along with climate, soil type, and slope when assessing hydrologic vulnerability of a site. Furthermore, land managers should consider the effects of litter removal when deciding to burn a site. We did not investigate fire effects in this study, but clearly the complete removal of litter from tree areas would exacerbate the effects of soil water repellency on runoff and erosion, and would increase the spatial area and potential connectivity of bare soil patches.

\section{ACKNOWLEDGMENTS}

The authors wish to thank Jaime Calderon and Matthew Frisby for assistance with data collection. We also thank the Desert Research Institute, Reno, Nevada, for assistance with processing the numerous soil samples.

\section{LITERATURE CITED}

Bates, J., R. F. Miller, and T. S. Svejcar. 2000. Understory dynamics in cut and uncut western juniper woodlands. Journal for Rangeland Management 53:119-126.

Bisdom, E. B. A., L. W. Dekker, and J. F. T. Schoute. 1993. Water repellency of sieve fractions from sandy soils and relationships with organic material on soil structure. Geoderma 56:105-118.

BLACKBURN, W. H. 1975. Factors influencing infiltration and sediment procedures of semiarid rangelands in Nevada. Water Resources Research 11:929-937. 
Bonnin, G. M., D. Martin, B. Lin, T. Parzybok, M. Yekta, and D. Riley. 2006. Precipitation-frequency atlas of the United States. NOAA Atlas 14, Volume 1, Version 4.0. Silver Spring, MD, USA: National Oceanic and Atmospheric Administration, National Weather Service. $261 \mathrm{p}$.

Breshears, D. D., O. B. Myers, S. R. Johnson, C. W. Meyer, and S. N. Martens. 1997. Differential use of spatially heterogeneous soil moisture by two semiarid woody species: Pinus edulis and Juniper monosperma. Journal of Ecology 85:289-299.

Breshears, D. D., J. W. Nyhan, C. E. Heil, and B. P. Wilcox. 1998. Effects of woody plants on microclimate in a semiarid woodland: soil temperature and evaporation in canopy and intercanopy patches. International Journal of Plant Science 159:1010-1017.

Bunting, S. C., J. L. Kingerly, E. Strand. 1999. Effects of succession on species richness of the western juniper woodland/sagebrush steppe mosaic. In: S. B. Monsen, S. Richards, R. J. Tausch, R. F. Miller, and C.. Goodrich [comps.] Proceedings: Ecology and Management of Piñon-Juniper Communities Within the Interior West; 15-18 September 1997; Provo, UT, USA. Ogden, UT, USA: US Department of Agriculture, Forest Service. RMRS-P-9. p. 76-81.

BuRkHard, J. W., AND E. W. TISDALE. 1969. Nature and successional status of western juniper vegetation in Idaho. Journal of Range Management 22 264-270.

Carter, C. E., J. D. Greer, H. J. Braud, and J. M. Floyd. 1974. Raindrop characteristics in south central United States. Transactions of the American Society of Agricultural Engineers 17:1033-1037.

Davenport, D. W., D. D. Breshears, B. P. Wilcox, and C. D. Allen. 1998. Viewpoint: Sustainability of pinyon-juniper ecosystems-a unifying perspective of soil erosion thresholds. Journal of Range Management 51:231-240.

Debano, L. F. 1981. Water-repellent soils: a state of the art. Berkeley, CA, USA: US Department of Agriculture, Forest Service. PSW-GTR-46. $21 \mathrm{p}$.

Doescher, P. S., L. E. Eddleman, and M. R. VaitKus. 1987. Evaluations of soil nutrients, $\mathrm{pH}$, and organic matter in rangelands dominated by western juniper. Northwest Science 61:97-102.

GiFFoRD, C. F. 1985. Cover allocation in rangeland watershed management: a review. In: E. B. Jones and T. J. Ward [EDS.]. Watershed Management in the Eighties. Proceedings of the Symposium sponsored by the Committee on Watershed Management of the Irrigation and Drainage Division of the American Society of Civil Engineers in conjunction with the ASCE Convention; 30 April-1 May 1985; Denver, CO, USA. New York, NY, USA: American Society of Civil Engineers. p. 23-31.

Grossman, R. B., and F. B. Pringle. 1987. Describing soil surface properties-their seasonal changes and implications for management in soil survey techniques. Soil Science Society of America, Special Publication 20:57-75.

Herrick, J. E., J. W. Van Zee, K. M. Havstad, L. M. Burkett, and W. G. Whitford. 2001. Field soil aggregate stability kit for soil quality and rangeland health evaluations. Catena 44:27-35.

Herrick, J. E., W. G. Whitford, A. G. de Soyza, J. W. Van Zee, K. M. Havstad, C. A. Seybold, and M. Walton. 2005. Monitoring manual for grassland, shrubland, and savanna ecosystems. Vol. 1: quick start. Las Cruces, NM, USA US Department of Agriculture, Agricultural Research Service, Jornada Experimental Range. $36 \mathrm{p}$

Holland, M. E. 1969. Colorado State University experimental rainfall-runoff facility, design, and testing of rainfall system. Fort Collins, CO, USA: Colorado State University, Colorado State University Experimental Station, Technical Report CER 69-70 MEH. 21 p.

Littell, R. C., G. A. Milliken, W. W. Stroup, R. D. Wolfinger, and 0. Schabenberger. 2006. SAS for mixed models. Cary, NC, USA: SAS Institute Inc. 814 p.

Ludwig, J. A., D. J. Tongway, D. O. Freudenberger, J. C. Noble, and K. C. Hodgkinson. 1997. Landscape ecology, function and management: principles from Australia's rangelands. Melbourne, Australia: CSIRO Publishing. 158 p.

Ludwig, J. A., B. P. Wilcox, D. B. Breshears, D. J. Tongway, and A. C. Imeson. 2005. Vegetation patches and runoff-erosion as interacting ecohydrological processes in semiarid landscapes. Ecology 86:288-297.

Mclver, J. D., M. Brunson, S. Bunting, J. Chambers, N. Devoe, P. Doescher, J. Grace, D. Johnson, S. Knick, R. Mlller, M. Pellant, F. Pierson, D. Pyke, K. Rollins, B. Roundy, G. Schupp, R. Tausch, And D. Turner. 2010. SageSteP: a region-wide experiment to evaluate effects of fire and fire surrogate treatments in the sagebrush biome. Fort Collins, CO, USA: US Department of Agriculture, Forest Service, RMRS-GTR-237. 16 p.

MeEUWIG, R. O. 1971. Infiltration and water repellency in granitic soils. Ogden, UT, USA: US Department of Agriculture, Forest Service, IFRES-INT-111. 22 p.

Meyer, L. D., And W. C. Harmon. 1979. Multiple-intensity rainfall simulator for erosion research on row sideslopes. Transactions of the American Society of Agricultural Engineers 22:100-103.

Miller, R. F., J. D. Bates, T. J. Svejcar, F. B. Pierson, and L. E. Eddleman. 2005. Biology, ecology, and management of western juniper (Juniperus occidentalis). Corvallis, OR, USA: Oregon State University Agricultural Experiment Station, Technical Bulletin 152. $82 \mathrm{p}$.

Miller, R. F., T. J. Svejcar, and J. R. Rose. 2000. Impacts of western juniper on plant community composition and structure. Journal of Range Management 53:574-585.

MILLER, R. F., AND R. J. TAUSCH. 2001. The role of fire in pinyon and juniper woodlands: a descriptive analysis. In: K. E. M. Galley and T. P. Wilson [EDS.]. Proceedings of the Invasive Species Workshop: the Role of Fire in the Control and Spread of Invasive Species. Fire Conference 2000: the First National Congress on Fire Ecology, Prevention, and Management; 27 November-1 December 2000; San Diego, CA, USA. Tallahassee, FL, USA: Tall Timbers Research Station, Miscellaneous Publication No. 11. p. 15-30.

Miller, R. F., R. J. Tausch, E. D. McArthur, D. D. Johnson, and S. C. Sanderson. 2008. Age structure and expansion of piñon-juniper woodlands: a regional perspective in the intermountain west. Fort Collins, CO, USA: US Department of Agriculture, Forest Service, RMRS-RP-69. $15 \mathrm{p}$.

Miller, R. F., and P. E. Wigand. 1994. Holocene to changes in semiarid pinyonjuniper woodlands: Response to climate, fire, and human activities in the US Great Basin. Bioscience 44:465-474.

Moffet, C. A., F. B. Pierson, P. R. Robichaud, K. E. Spaeth, and S. P. Hardegree. 2007. Modeling soil erosion on steep sagebrush rangeland before and after prescribed fire. Catena 71:218-228.

Mueller-Dombois, D., and H. Ellenberg. 1974. Aims and methods of vegetation ecology. New York, NY, USA: John Wiley and Sons. $570 p$

[NRCS] Natural Resources Conservation Service. 2006. Soil Survey Geographic (SSURGO) database for Tooele Area, Utah-Tooele County and parts of Box Elder, Davis, and Juab counties, Utah, White Pine and Elko counties, Nevada. Fort Worth, TX, USA: US Department of Agriculture, Natural Resources Conservation Service. $611 \mathrm{p}$.

[NRCS] Natural Resources Conservation Service. 2007. Soil Survey Geographic (SSURG0) database for western White Pine County area, Nevada, parts of White Pine and Eureka counties. Fort Worth, TX, USA: US Department of Agriculture, Natural Resources Conservation Service. 780 p.

Padien, D., and K. Lautha. 1992. Plant spatial pattern and nutrient distribution in pinyon-juniper woodlands along an elevational gradient in northern New Mexico. Journal of Plant Science 153:425-433.

Petersen, S. L., and T. K. Stringham. 2008. Infiltration, runoff, and sediment yield in response to western juniper encroachment in southeast Oregon. Rangeland Ecology and Management 61:74-81.

Pierson, F. B., J. D. Bates, T. J. Svejcar, and S. P. Hardegree. 2007a. Runoff and erosion after cutting western juniper. Rangeland Ecology and Management 60:285-292.

Pierson, F. B., W. H. Blackburn, and S. S. Van Vactor. 2007b. Hydrologic impacts of mechanical seeding treatments on sagebrush rangelands. Rangeland Ecology and Management 60:666-674.

Pierson, F. B., W. H. Blackburn, S. S. Van Vactor, and J. C. Wood. 1994. Partitioning small scale spatial variability of runoff and erosion on sagebrush rangeland. Water Resources Bulletin 30:1081-1089.

Pierson, F. B., D. H. Carlson, and K. E. Spaeth. 2002. Hydrologic impacts of fire on steep intermountain sagebrush-steppe rangeland. Intermountain Journal of Wildland Fire 11:145-151.

Pierson, F. B., C. A. Moffet, C. J. Williams, S. P. Hardegree, and P. E. Clark. 2009. Prescribed-fire effects on rill and interrill runoff and erosion in a mountainous sagebrush landscape. Earth Surfaces Processes and Landforms 34:193203. 
Pierson, F. B., P. R. Robichaud, C. A. Moffet, K. E. Spaeth, S. P. Hardegree, P. E. Clark, AND C. J. WiLLIAMs. 2008a. Fire effects on rangeland hydrology and erosion in a steep sagebrush-dominated landscape. Hydrological Processes 22:29162929.

Pierson, F. B., P. R. Robichaud, C. A. Moffet, K. E. Spaeth, C. J. Williams, S. P. Hardegree, and P. E. Clark. 2008b. Soil water repellency and infiltration in coarse-textured soils of burned and unburned sagebrush ecosystems. Catena 74:98-108.

Pierson, F. B., P. R. Robichaud, and K. E. Spaeth. 2001. Spatial and temporal effects of wildfire on the hydrology of a steep rangeland watershed. Hydrological Processes 15:2905-2916.

PrISM Group. 2009. Prism Climate Group, Oregon State University. Available at: http://prismmap.nacse.org/nn/index.phtml. Accessed 23 September 2009.

Reid, K. D., B. P. Wilcox, D. D. Breshears, and L. MacDonald. 1999. Runoff and erosion in a piñon-juniper woodland: influence of vegetation patches. Soil Science Society of America Journal 63:1869-1879.

Ritsema, C. J., And L. W. Dekker. 1994. How water moves in a water-repellent soil: 2. Dynamics of fingered flow. Water Resources Research 30:2519-2531.

Ritsema, C. J., And L. W. Dekker. 1995. Distribution flow: A general process in the top layer of water repellent soils. Water Resources Research 31:1187-1200.

Ritsema, C. J., L. W. DekkeR, J. M. H. Hendrickz, and W. Hamminga. 1993. Preferential flow mechanism in a water repellent sandy soil. Water Resources Research 28:2183-2193.

Roberts, C., AND J. A. Jones. 2000. Soil patchiness in juniper-sagebrush-grass communities of central Oregon. Plant and Soil 223:45-61.

Romme, W. H., C. D. Allen, J. D. Balley, W. L. Baker, B. T. Bestelmeyer, P. M. Brown, K. S. Elsenhart, M. L. Floyd, D. W. Huffman, B. F. Jacobs, R. F. Miller, E. H. Muldavin, T. W. Swetnam, R. J. Tausch, and P. J. Weisberg. 2009. Historical and modern disturbance regimes, stand structures, and landscape dynamics in piñon-juniper vegetation of the western United States. Rangeland Ecology and Management 62:203-222.

Roundy, B. A., W. H. BlackBurn, and R. E. Eckert, JR. 1978. Influence of prescribed burning on infiltration and sediment production in the pinyon-juniper woodland, Nevada. Journal of Range Management 31:250-253.
SAS Institute. 1999. SAS System Software, release 8.0 edition. Cary, NC, USA: SAS Institute Inc. $1674 \mathrm{p}$.

Schlesinger, W. H., J. F. Reynolds, G. L. Cunningham, L. F. Huenneke, W. M. Jarrell, R. A. VIRGINIA, AND W. G. Whitford. 1990. Biological feedbacks in global desertification. Science 247:1043-1048.

TAusch, R. J., AND S. Hood. 2007. Pinyon/juniper woodlands. In: S. M. Hood and M. Miller [EDS.]. Fire ecology and management of the major ecosystems of southern Utah. Fort Collins, CO, USA: US Department of Agriculture, Forest Service, RMRS-GTR-202. p. 57-71.

Tausch, R. J., and P. T. Tueller. 1990. Foliage biomass and cover relationships between tree- and shrub-dominated communities in pinyon-juniper woodlands. Great Basin Naturalist 50:121-134.

Tausch, R. J., N. E. West. 1995. Plant species composition patterns with differences in tree dominance on a southwestern Utah piñon-juniper site. In: D. W. Shaw, E. F. Aldon, and C. LoSapio [TECH. COORDs.]. Proceedings: Desired Future Conditions for Piñon-Juniper Ecosystems US Department of Agriculture, Forest Service, GTR-RM-258; 8-12 August 1994; Flagstaff, AZ, USA. Fort Collins, CO, USA: US Department of Agriculture, Forest Service, Rocky Mountain Forest and Range Experiment Station. p. 16-23.

Tausch, R. J., N. E. West, and A. A. Nabi. 1981. Tree age and dominance patterns in Great Basin piñon-juniper woodlands. Journal of Range Management 34: 259-264.

WiLcox, B. P. 1994. Runoff and erosion in intercanopy zones of pinyon-juniper woodlands. Journal of Range Management 47:285-295.

Wilcox, B. P., D. D. Breshears, and C. D. Allen. 2003. Ecohydrology of a resourceconserving semiarid woodland: effects of scale and disturbance. Ecological Monographs 73:223-239.

Wilcox, B. P., J. Pitlick, C. D. Allen, and D. W. Davenport. 1996. Runoff and erosion from a rapidly eroding pinyon-juniper hillslope. In: M. G. Anderson and S. M. Brooks [EDS.]. Advances in hillslope processes. New York, NY, USA: John Wiley \& Sons. p. 61-71.

[WRCC] Western Regional Climate Center. 2009. Western U.S. climate historical summaries (individual stations). Available at: http://www.wrcc.dri.edu/Climsum. html. Accessed 23 September 2009. 